Columbia Law School

Scholarship Archive

1989

\title{
On the Nature of Bankruptcy: An Essay of Bankruptcy Sharing and the Creditor's Bargain
}

Thomas H. Jackson

Robert E. Scott

Columbia Law School, rscott@law.columbia.edu

Follow this and additional works at: https://scholarship.law.columbia.edu/faculty_scholarship

Part of the Banking and Finance Law Commons, and the Bankruptcy Law Commons

\section{Recommended Citation}

Thomas H. Jackson \& Robert E. Scott, On the Nature of Bankruptcy: An Essay of Bankruptcy Sharing and the Creditor's Bargain, 75 VA. L. REV. 155 (1989).

Available at: https://scholarship.law.columbia.edu/faculty_scholarship/385

This Article is brought to you for free and open access by the Faculty Publications at Scholarship Archive. It has been accepted for inclusion in Faculty Scholarship by an authorized administrator of Scholarship Archive. For more information, please contact scholarshiparchive@law.columbia.edu. 


\title{
VIRGINIA LAW REVIEW
}

VOLUME 75

MARCH 1989

NUMBER 2

\section{ON THE NATURE OF BANKRUPTCY: AN ESSAY ON BANKRUPTCY SHARING AND THE CREDITORS' BARGAIN}

\author{
Thomas H. Jackson* and Robert E. Scott**
}

IINANCE theorists have long recognized that bankruptcy is a key component in any general theory of the capital structure of business entities. Legal theorists have been similarly sensitive to the substantial allocational and distributional effects of the bankruptcy law. Nevertheless, until recently, underlying justifications for the bankruptcy process have not been widely studied. Bankruptcy scholars have been content to recite, without critical analysis, the two normative objectives of bankruptcy: rehabilitation of overburdened debtors and equality of treatment for creditors and other claimants.

The developing academic interest in legal theory has spurred a corresponding interest in expanding the theoretical foundations of bankruptcy law as well. One of us has developed over the past several years a conceptual paradigm, based on a hypothetical bargain among creditors, as a normative criterion for evaluating the bankruptcy system. ${ }^{1}$ The cornerstone of the creditors' bargain is the normative claim that prebankruptcy entitlements should be impaired in bankruptcy only when necessary to maximize net asset distributions to the creditors as a group and never to accomphish purely

* Arnold Leon Professor of Law and Dean, University of Virginia.

** Lewis F. Powell, Jr. Professor of Law and Member, Center for Advanced Studies, University of Virginia.

We would like to thank Doug Baird, Saul Levmore, John McCoid, Bill Young, and the participants im faculty workshops at Boston University and Columbia University for their helpful comments on an earlier version of this Article.

I See T. Jackson, The Logic and Limits of Bankruptcy Law (1986); Jackson, Translating Assets and Liabilities to the Bankruptcy Forum, 14 J. Legal Stud. 73 (1985); Jackson, Avoiding Powers in Bankruptcy, 36 Stan. L. Rev. 725 (1984); Jackson, Bankruptcy, NonBankruptcy Entitlements, and the Creditors' Bargain, 91 Yale L.J. 857 (1982) [hereinafter Jackson, Creditors' Bargain]. 
distributional goals. ${ }^{2}$

The strength of the creditors' bargain conceptualization is also its limitation. The hypothetical bargain metaphor focuses on the key bankruptcy objective of maximizing the welfare of the group through collectivization. This single-minded focus on maximizing group welfare helps to identify the underlymg patterns in what appear to be unrelated aspects of the bankruptcy process. It also implies that other normative goals should be seen as competmg costs of the collectivization process. Yet this claim uncovers a further puzzle. Despite the centrality of the maximization norm, persistent and systematic redistributional impulses are apparent in bankruptcy. Is redistribution in bankruptcy simply attributable to random errors or misperceptions by courts and legislators? Or are other forces present in the bankruptcy process as well?

In this Article we undertake to examine the "other forces" that may be at work in bankruptcy. ${ }^{3}$ Many bankruptcy rules require sharing of assets with other creditors, shareholders, and third parties. Too often these distributional effects are grouped together under general references to equity, wealth redistribution, or appeals to communitarian values. These labels are unhelpful. They disguise the fact, for instance, that the justification and impact of consensual risk sharing among creditors is entirely different in character from the rationale for using bankruptcy to redistribute wealth to nonconsensual third parties. Understanding these diverse effects requires, therefore, a method of discriminatimg among the different motivations that impel redistributions in bankruptcy.

In Part I, we reconstruct and embellish the original creditors' bargain model by relaxing several of the implicit assumptions underlying the ex ante bargam. Within this framework, we examine more precisely the contours of

2 One of the touchstones of this model is that, while a collective regime such as bankruptcy is sometimes necessary as a device to induce cooperative behavior, redistribution in the collective regime only induces self-interested action by particular clainants that may be inconsistent with the interests of the claimants as a group. This model seeks to ensure that distributional concerns do not interfere with the central goal of maximizing the deployment of assets to all claimants. One method of accoinplishing this objective is to minimize the distinctions in treatment of individual claimants between the two debt-collection regimes.

3 We put aside financial "fresh start" notions that often are preeminently relevant for individuals who seck bankruptcy to discharge past debts. The fresh start norm insulates future income (and certain other assets) froin the claims of past indebtedness. This policy, which requires sharing certain assets with the "debtor," has no relevance (except soinetimes rhetorically) for corporate debtors. Corporate debtors get no discharge in ordinary bankruptcy proceedings, see 11 U.S.C. $\S 727$ (a)(1) (1982), and the "discharge" in Chapter 11, 11 U.S.C. $\S 1141$ (1982 \& Supp. IV 1986), is best seen as consummating the "swap" of old clains for new claims that occurs in a reorganization. We do not address in this Article the fresh start policy for individuals in bankruptcy. 
the original creditors' bargain to see if any purportedly redistributional concerns of bankruptcy law reflect a part of the ex ante agreement. To the extent that they do, it is then mcorrect to say as a matter of theory that there is a conflict between bankruptcy's distributional goals and the creditors' bargain.

This expanded framework illuminates an important distributional principle that underhes a richer version of the creditors' bargain. Under this principle, all participants share (at least in part) the risks of busmess failure attributable to certain "common disasters." We argue that those distributional effects premised on the anticipation of these common disasters would be explicitly included in an ex ante bargam, so long as the costs of implementation did not outweigh the benefits in enhancing the creditors' wealth. ${ }^{4}$

In Part II, we examine whether an expanded framework that incorporates a common disaster component to business failure helps to explain at least some of the various distributional effects commonly observed in bankruptcy. We test the model agamst three features of the bankruptcy process: (1) the extraordinary powers of collection and enhancement of the estate afforded the bankruptcy trustee; (2) the imposition of "delay" costs on secured creditors during the bankruptcy process; and (3) the impleinentation of Chapter 11 reorganization plans. We conclude from this analysis that the common disaster conception both enriches and supports the heuristic value of the ex ante bargain. Indeed, the expanded bargain model rationalizes a number of the apparent anoinalies that heretofore have eroded the explanatory power of the original creditors' bargam conception. At least in theory, the expanded model accounts for many of the distributional effects that appear regularly throughout the bankruptcy process.

The theoretical appeal of the expanded model is dampened, however, by its siguificant limitations once impleinentation costs are reintroduced. Except for across-the-board provisions such as the denial of postpetition interest to secured creditors, the impulse for redistribution in bankruptcy seenis to founder on an inability of the system to distinguish between favored and disfavored distributions. Indeed, the problem is basic. Absent a refined selection mechanism that permits such distinctions, distributional considerations that differ fronı those used outside of bankruptcy will inevitably impair the realization of bankruptcy's collective goals.

We conclude, therefore, that to the extent that the bankruptcy process embraces diverse distributional goals, it inevitably generates significant off-

4 This common disaster conceptualization was first suggested in Scott, A Relational Theory of Secured Financing, 86 Colum. L. Rev. 901, 967-68 (1986) [hereinafter Scott, Relational Theory], and further developed in Scott, Through Bankruptcy with the Creditors' Bargain Heuristic, 53 U. Chi. L. Rev. 690, 700-07 (1986) [hereinafter Scott, Through Bankruptcy]. 
setting costs, even when those goals are consistent with implementing a common disaster component in the ex ante bargain. These costs result both from the perverse incentives resulting from a different ordering of entitlements inside and outside of bankruptcy, and from the inherent incapacity of the legal system to specify ex ante rules for implementing ex post distributional principles. Whether the benefits of reflecting the expanded bargaim model in the rules of bankruptcy are worth the implementation costs ultimately is an empirical question. That the tradeoff exists, however, invites renewed attention as well to the question of selection rules that aid in distinguishing the uses of bankruptcy that further the ex ante bargain from those that further the interests of only one group, at the expense of the whole.

\section{AN EXPanded Model of the CReditors' Bargain}

\section{A. Reconstructing the Creditors' Bargain}

\section{Background Assumptions and Starting Points ${ }^{5}$}

A primary objective of any bankruptcy process is to regulate the inherent conflicts ainong different groups having separate claims against a debtor's assets and income streain. Although inany classes of claimants may exist, the most common corporate structure usually consists of secured creditors, unsecured creditors, and equity (common stockholders). The relations among classes are governed both by contracts and by legal rules prescribing attributes of the various classes. We focus here on the case of default and insolvency, for the interclass conflicts generated by such a state of the world pose particular problems.

Because lower classes (equity interests and often general creditors) fare so poorly in any hiquidation that follows insolvency, they are likely to want the debtor to continue in business. Cash-outs collapse probability distributions and thus are unattractive to the residual interests that benefit from upside potential. This is almost certainly the case with equity owners, whose interests are worth something if the debtor continues but are, by definition,

5 There are several ways to examine complex phenomena such as bankruptcy. One method is to develop a conceptual model with a clear normative perspective and to consider whether the bankruptcy process either reflects or deviates from the stated norm. An alternative approach is to attempt a positive analysis of the bankruptcy process, using a descriptive or explanatory model. One of us has already undertaken a inajor project of the first sort. We now search for the additional insights available through a process that begins with the second method and then returns to the conceptual model to suggest improvements to it. Sec $T$. Jackson, supra note 1 . Thus, our objective is to provide a richer normative theory of the bankruptcy process by enhancing the explanatory power of the original model. Obviously, as with all analytic tools, the distinction betwcen these two approaches is not as clean as their several adherents would assert. This should not surprise anyone who subscribes to the view that persistent social institutions rest on purposive foundations. 
worthless in the liquidation of an insolvent company. Accordingly, at least one class, and perhaps others, will expect to realize inore from its claims if an insolvent debtor is given a chance to recover than if the debtor is promptly hiquidated. ${ }^{6}$ These classes frequently (and sometimes successfully) use legal mechanisms to forestall the liquidation of busimess debtors. On the other hand, creditors whose claims are well protected by security interests generally prefer the certain return from a prompt foreclosure. After all, the busmess position of an insolvent debtor can deteriorate as well as improve, and if it does deteriorate, fewer assets inay remain for secured parties. While contract terms such as adjustable interest rates can compensate secured creditors ex post for some of these risks, the rates are likely to be adjusted too hittle, too late.

Reconciling the tensions among the individual interests of claimants of an imsolvent debtor poses an obvious problem, one unlikely to be resolved collectively without legal intervention. Furthermore, because the interests of various classes differ, it is unclear who should hold the decisionmaking power once collective action begins. The problem of transferring decisionmaking power from the equity owners (who normally hold it subject to certain contractual and legal restrictions) is compounded by the associated problem that no other class inay sufficiently reflect the interests of the claimants taken as a whole. Thus, tlie objective of the collective is never entirely congruent with the objective of any of the constituent parts.

Even after collective action begins, the choice between liquidation and rehabilitation will often be difficult. If the going concern value of the firm exceeds its hquidation value, then the debtor's claimants as a group would prefer not to have the firm hiquidated but rather would prefer to have the business sold as a debt-free entity. ${ }^{7}$ Indeed, if the debtor's long-term prospects were sufficiently bright, the claimants would prefer to delay collection altogether and allow the debtor to recover. Going concern value does not exceed liquidation value in all cases, however. The assnmption of greater going concern value depends upon the existence of two factors: the debtor's assets must be worth more in combimation than if they were broken up and sold, and the long-term prospects of the debtor must be brighter than the short-term prospects. In cases where either of these factors does not hold, total group welfare would be enhanced by a prompt liquidation of the

6 Insolvency and bankruptcy do not necessarily go hand-in-hand. A firm may not be insolvent, yet may have creditors act as if it is because of a high enough probability that it will be insolvent. For example, a firm that owes $\$ 100$ and has a 50\% chance of being worth $\$ 200$ in a year's time and a 50\% chance of being worth $\$ 50$ then, has an expected value of $\$ 125$ Inore than liabilities. Yet, the creditors may well act as if the firm were insolvent.

7 This discussion of the choice between going concern and liquidation value puts aside tax considerations, which are important factors in many real-world cases. 
debtor, as opposed to a collective proceeding in which some interests might gain greater shares at the expense of others.

A principal justification for bankruptcy law, then, is to provide incentives for individual claimants such that each of them, as well as constituent groups, finds it optimal either to wait or to collect immediately, depending on the underlying empirical realities and on the interests of the claimants as a whole. Whichever course the law encourages parties to take, maximizing the total welfare of the group will necessarily be the central objective. The dilemma, however, is that the law cannot ensure that the interests of any particular group of claimants will coincide with this interest of the whole. Thus, allocation of decisionmaking power in bankruptcy is likely to be difficult and to reflect only imperfectly the group goal, even if that group goal is easy to articulate.

\section{The Bargain Redux}

In seeking to understand how bankruptcy law impleinents a general objective of maximizing group welfare, one can usefully inagine "bankruptcy as a system designed to mirror the agreenent one would expect the creditors to forin among theinselves were they to negotiate such an agreement froin an ex ante position."8 A central premise underlying this creditors' bargain conceptualization is that a system of state law entitlements (including priorities ainong secured and unsecured creditors) is already in place and that parties know what their priority positions will be so long as state law continues to govern their rights. Given these background conditions, the question is whether the parties would nevertheless agree to a collective scheine of distribution, and, if so, what form would it take? If we assume that commercial parties are rational and self-interested, this hypothetical bargain analysis provides indirect evidence of what real world parties would, in fact, agree to. The hypothetical bargain thus yields a norinative criterion, grounded on principles of autonoiny, for evaluating the legitimacy of the bankruptcy process.

The creditors come to the bargain, then, with their individual state law entitlements intact. It is logical, therefore, to begin by assuming that insolvency is a foreseeable risk - one that will be borne individually by the various claimants. The calculation of this risk will have influenced individual creditors' decisions as to whether a security interest should be taken and, if so, on what terins. This assumption suggests that the agreenent hammered out in the creditors' bargain would respect those prebankruptcy entitle-

8 Jackson, Creditors' Bargain, supra note 1, at 860 . A similar conceptualization is developed in Baird, A World Without Bankruptcy, Law \& Contemp. Probs., Spring 1987, at 173. 
ments, even when it is in the interest of the group to move from an individual to a collective regime such as bankruptcy. Secured creditors, for example, would have paid for their priority position by accepting a lower rate of return and should therefore be allowed to retain the benefits of their initial bargain by receiving an equivalent value for their collateral in bankruptcy. Unsecured creditors, on the other hand, would have obtained a higher interest rate by forgoing security and in so doing would have assumed a greater risk that their claims would not be fully satisfied upon default and subsequent bankruptcy. The participants in the bankruptcy bargain could thus be expected to honor this relationship by inaintaining the secured creditors' nonbankruptcy entitlements and by preventing redistribution in bankruptcy froin secured creditors to unsecured creditors and the debtor. ${ }^{9}$

This basic argument is supported by two further observations. First, unless the rules regulating bankruptcy access were perfectly drawn, the recognition that bankruptcy provides a method of distributing entitleinents that differs from state law would create incentives that would inotivate parties to use the bankruptcy process strategically. ${ }^{10}$ Unsecured creditors and equity owners would opt for bankruptcy when their share of the bankruptcy estate exceeded the value of their entitleinents under state law. These actions would be undesirable whenever the expectation of a greater share stemmed solely from the claimant's ability to use the bankruptcy process strategically to delay hquidation. ${ }^{11}$ Secured creditors, on the other hand, would prefer nonbankruptcy law if bankruptcy would force thein to share their state law entitlements. Furthermore, once the ex ante bargain is struck, individual claimants would thereafter bargain in the shadow of both nonbankruptcy and bankruptcy law, exploiting provisions unfavorable to the opposing side as a ineans of obtaining a favorable readjustment of their bargained-for enti-

9 Scott, Through Bankruptcy, supra note 4 , at $694-95$.

10 The problem of perverse incentives and the relationship between bankruptcy and nonbankruptcy law is thoughtfully analyzed in Eisenberg, Bankruptcy Law in Perspective, 28 UCLA L. Rev. 953 (1981), and Shanker, The Abuse and Use of Federal Bankruptcy Power, 26 Case W. Res. L. Rev. 3 (1975). This problem is also the focus of the Uirited States Supreme Court's choice of an appropriate "gap-filling" rule in Butner v. United States, 440 U.S. 48 (1979) (party in federal bankruptcy court should be afforded the same protection that would have been granted under state law had bankruptcy not ensued).

11 Cases that are essentially two-party disputes (between equity owners and a dominant creditor) are generally thought to be inappropriate for bankruptcy. See, e.g., Little Creek Dev. Co. v. Coinmonwealth Mortgage Corp. (In re Little Creek Dev. Co.), 779 F.2d 1068 (5th Cir. 1986); Meadowbrook Investors' Group v. Thirtieth Place, Inc. (In re Thirtieth Place, Inc.), 30 Bankr. 503 (Bankr. 9th Cir. 1983). But cf. In re Cordova, 34 Bankr. 70 (Bankr. D.N.M. 1983) (single-creditor involuntary bankruptcy appropriate because bankruptcy process could sell ongoing business better than the court). 
tlements. ${ }^{12}$ As parties maneuver strategically to obtain the most favorable individual outcome, they generate unnecessary social costs, mcluding a costly enforcement structure and a narrowing of the distmctions among different classes of claimants. ${ }^{13}$

The second reason to behieve that the parties to an ex ante bargain would preserve prebankruptcy entitlements in bankruptcy is that secured creditors would otherwise be unwilling to join in a bankruptcy process from which they derive no advantage. Mandatory inclusion of secured creditors is necessary for unsecured creditors and those jumior to them to enjoy the fruits of collective action. Only by agreeing to such a collectivization process can the claimants solve the anticipated problems of noncooperation and ensure an imcreased pool of assets for distribution to all creditors.

\section{The Problem of Distributional Effects}

This simple creditors' bargam conception focuses on maximizing group welfare through collectivization. It is concerned with distribution only insofar as bankruptcy distributions either undermine the sharing rules of the ex ante bargain or promote inefficiencies through strategic forum shopping. Yet the distinction between maximization of group welfare and distribution within the group is not so clear. Any collectivization procedure necessarily has both a redistributive and an allocative effect. In order to implement a collective system of distribution, individual creditors must be restrained from exercising entitlements that they would otherwise enjoy under state law. There will obviously be an interference with prebankruptcy rights; there will also, however, almost inevitably be a change in the relative value of those prebankruptcy rights. It is too costly to determine and respect relative

12 Scott, Through Bankruptcy, supra note 4, at 695; see Note, The Proper Discount Rate Under the Chapter 11 Cramdown Provision: Should Secured Creditors Retain Their State Law Entitlements?, 72 Va. L. Rev. 1499, 1502 (1986). Under this view, of course, rule changes that are favorable to senior classes are equally as undesirable as rule changes favorable to junior classes. See Eisenberg, The Undersecured Creditor in Reorganizations and the Nature of Security, 38 Vand. L. Rev. 931 (1985).

13 One can best visualize this dilution, and its effect on differentiated capital structures, by examining the extreme: the case where bankruptcy is freely available and the distribution rule in bankruptcy is a strict pro rata sharing rule. In those cases, unless accurate sorting mechanisins could be devised, one would expect the priority distinctions between secured and unsecured debt largely to disappear, leaving as the sole advantage of secured debt the twoparty default rights (such as self-help repossession). Such a regime would conflict with any starting point that recognized efficiencies in the taking of seeured credit in the first place. And if there were no such efficiencies, the simple solution would be to bar seeured credit instead of establishing a second forum for debt collection that plays by different distributional rules. See Jackson \& Kroninan, Secured Financing and Priorities Among Creditors, 88 Yale L.J. 1143, 1147-49 (1979); Scott, Relational Theory, supra note 4, at 925-33, 969-70. 
values im full in a collective proceeding. ${ }^{14}$ Compromises are inevitable in order to preserve the efficiencies of the collective regime. If those distributional effects are tolerated because they promote the central objective of maximizing group welfare, it is appropriate to ask whether other distributional effects might be similarly understood.

By excluding such a distributional analysis, the simple maximization perspective treats as indistinguishable - and equally undesirable-the various distributional effects that are unambiguously present in bankruptcy. ${ }^{15}$ It is obvious, however, that not all bankruptcy distributions are alike. The redistribution that we observe im bankruptcy cases may be caused by several conceptually distimct factors. Indeed, a complete typology of the possible motivations for bankruptcy redistribution would include at least seven discrete categories: (1) "equitable" redistributions by bankruptcy courts; (2) errors and misperceptions owing to imperfections in legal rules; (3) "unprincipled" redistributions resulting from the strategic mampulation of the bankruptcy process; (4) consensual risk sharing among creditors; contribution among creditors to reduce "eve of bankruptcy" conflicts of interest; (6) redistributions to preserve the "ownership" interest of certain equity interests; and (7) redistributions to benefit nonconsensual claimants and other third parties.

The uncertam genesis of particular bankruptcy redistributions means that broad generalizations about the costs and benefits of redistribution in bankruptcy are virtually meaningless. A more fruitful approach is to assess the effects of particular redistributions given certain plausible assumptions. The issue then becomes whether any bankruptcy redistributions can be seen as the means of implementing, rather than undernining, the original distribution implicit in the ex ante bargain. ${ }^{16}$ We begin by reconsidering several

14 The same point applies to rules that decide when bankruptcy is appropriate and who makes the relevant decisions once in bankruptcy.

15 The problem of strategic forum shopping is the major impediment to selecting any desired set of distributional rules in bankruptcy. Therefore, if the rules governing access to bankruptcy appropriately screened just for cases presenting collective action problems and could be easily applied, any set of distributional rules in bankruptcy could be adopted. For example, one could have a set of rules under which all creditors shared equally. The only impact of that rule would be to erode the distinctions among classes of creditors. For a debate over bankruptcy policy focusing on the extent to which forum shopping is a real or only a perceived impediment to broader distributional analysis, see Warren, Bankruptcy Pohicy, 54 U. Chi. L. Rev. 775 (1987); Baird, Loss Distribution, Forum Shopping, and Bankruptcy: A Reply to Warren, 54 U. Chi. L. Rev. 815 (1987).

16 The purpose of this inquiry is to develop a richer normative justification for the bankruptcy process. If maximization and redistribution are, in fact, coinplementary goals, the more coherent are the core normative premises of the bankruptcy process. Furthermore, if botli collectivization and distribution can be seen, at least in theory, as the product of an ex ante bargain, this supports the claim that the rules are fair. Thus, the theoretical argument has 
basic assumptions of the original creditors' bargain model to see if they hold a key to the puzzle of redistribution in bankruptcy.

\section{B. Bankruptcy Sharing and the Common Disaster}

A central premise of the simple creditors' bargain is that redistribution in bankruptcy is inconsistent with the maximizing objectives of the collective. Insolvency is seen as a foreseeable risk that is borne individually by the various claimants of any business enterprise. Thus, the inodel assuines, inter alia, that none of the risks of business failure will be shared ainong claimants of different classes, except as otherwise explicitly agreed. ${ }^{17}$

As a starting point for reexamination, we focus critically on this assumption. Consider the possibility that the bankruptcy process reflects a normatively satisfactory accommodation between the objective of asset inaximization and a complementary distributional norm: that all participants should share (at least in part) in the "common" risks of business failure. Common risks include those contingencies whose probabilities or effects cannot be influenced by the actions of individual parties, contingencies that are, in consequence, coinmon to the affected group of claimants. Cominon risks are thus distinct from the individual or particular risks of business failure that can be attributed to a single group, such as risks arising out of incompetent or dishonest manageinent for which the shareholders as a group are "responsible." Perhaps certain redistributions in bankruptcy can be understood as a response to the effects of such common disasters on business enterprises.

\section{Allocating Insolvency Risks Under Uncertainty \\ a. Strategies for Reducing Insolvency Risks}

The risks of business failure do not all arise from the saine source, nor would claimants necessarily treat all of them in the same way. Some risks of insolvency arise from contingencies whose probabilities or effects can be influenced by the actions of particular parties or groups. In these cases, one party or another can act in a way that will alter the objective ainount of risk that is created. When such precautionary actions are cost-beneficial, all parties will gam from agreement on a binary strategy of risk control: assigning the entire risk of a particular contingency to the party (or group) best able to influence the amount of the risk. Shareholders, for example, are assigned the

value independent of the extent to which these two norms can be successfully accommodated in any real-world bankruptcy system.

17 From this assumption it follows that a collective proceeding associated with insolvency exists to solve collective action problems only, and not to readjust who bears what risks. Seen in that light, redistributions indeed seem counterproductive and normatively undesirable. 
insolvency risks arising from defalcations or incoinpetence of the firm's managers because they are best able to inonitor the managers' performance. If bankruptcy claimants used a strategy of risk control, they would agree that all the risks of business failure would be borne individually. ${ }^{18}$

The advantage of bearing insolvency risks individually derives from the ability of each creditor to exercise some control over its own relationship with the debtor. Individual creditors may wish to inomitor the debtor's behavior in different ways or to invest varying amounts in precautionary activities, so as to best reduce the risks that the debtor will not repay the loan or diligently pursue the financial prospect. Individual claimants will cost out these risks by arranging for an optimal combination of price and security.

Individualized risk bearing will predictably result in a mix of debt and equity, secured and unsecured credit. This variety will clearly be desirable for a wide range of busmess risks. There is substantial evidence that, in certain classes of transactions, secured credit functions as a umique contractual mechamism for controlling the conflicts of interest that otherwise hinder the developinent of business prospects that are financed by private debt. ${ }^{19}$ Individually borne risk allocations thus enable debtors to obtain the mix of secured and unsecured debt that best controls debtor-creditor conflict.

Under some circumstances, parties to a creditors' bargain might also be motivated to pursue a coinplementary strategy: transferring risks to others who have greater tolerance for the consequences of a risk. This strategy of risk transfer would be sensible if various creditors attached different subjective values to the same risk. If the creditors had different preferences for risk, then a risk would best be borne by whichever creditor placed the lowest money cost on it. Risk transfer thus reduces risk cost whenever a risk is allocated to a party who, if only for psychological reasons, attaches a lower money value to the risk. ${ }^{20}$

Risk control and risk transfer are complementary, binary strategies that reduce risk by allocating the entire risk to individual parties. As such, these binary strategies fit comfortably into the original creditors' bargain conception. All of the claimants would presuinably agree on a series of hierarchical priority rules to implement a scheine of individual risk assignments. Not all risks, however, are best borne by one group as opposed to another. Allocat-

18 The discussion of risk control, as well as the risk-bearing alternatives that are analyzed below, follows the discussion in Scott, Conflict and Cooperation in Long-Term Contracts, 75 Calif. L. Rev. 2005, 2012-18 (1987).

19 See Jackson \& Kronman, supra note 13; Levmore, Monitors and Freeriders in Commercial and Corporate Settings, 92 Yale L.J. 49 (1982); Scott, Relational Theory, supra note 4.

20 Scott, supra note 18 , at 2014. 
ing the risks of insolvency is considerably more complex if the parties also consider alternative, noncomplementary strategies. One possibility is risk sharing. By sharing the risk of events that are not especially in the control of one party or another, the parties can reduce the amount of uncertainty and thus potentially reduce the cost of the risk for some if not for all. ${ }^{21}$ Those claimants who are risk averse will benefit from a risk-sharing arrangement because it reduces the variance in risk; each party has a higher probability of incurring a smaller loss. ${ }^{22}$

Risk-sharing agreements, however, are costly to negotiate ex ante, because the parties inust settle vexing distributional questions. Moreover, the cost of measuring and dividing the product of the creditors' bargain will be higher under a risk-sharing scheme. In general, the more complex the "contractual product," the more challenging are the problems of measurement and division of responsibility. ${ }^{23}$ By contrast, imdividualized risk-bearing strategies are easier to adopt because they depend on relatively simple cognitive heuristics such as the assumption that each party can exercise some control over the endogenous variables that influence busmess risks. Because risk-sharing arrangements are inevitably more complex than a scheme of individual responsibility, evasion of the collective responsibility is more difficult to detect and to police. Consequently, the costs of enforcement are higher where the parties agree to share risks than where the parties bear their responsibilities individually.

The anticipated costs of risk sharing might suggest that such agreementš inevitably would be vetoed by the participants im the ex ante bargam. But the creditors' bargain of necessity involves long-term relationships im which many of the contingencies that influence business prospects are uncertain and highly interactive. In the case of such coinmon risks, no smgle claimant can influence the relative probabilities of the possible outcomes or predict the relationship among them. The relative desirability of any given precautionary action (such as the best means of guarding against particular types of misbeliavior by the debtor) will thus depend upon several interactive variables (such as what other creditors are also extending credit to the debtor and on whiat terms). Under these conditions, increased precautions by individual creditors will not return any systematic benefits. The parties to such

21 In Part I.B.2, see infra text accompanying notes 31-38, we explore admiralty law's general average contribution rule as an analogous method of imposing risk sharing in the face of common disasters. The analogy is equally suitable here.

22 A risk-averse party will discount a prospect's expected value in order to reflect dislike of the magnitude of the risk. Scott, supra note 18, at 2015.

${ }^{23}$ See Cheung, Transaction Costs, Risk Aversion, and the Choice of Contractual Arrangeinents, 12 J.L. \& Econ. 23 (1969); Umbeck, A Theory of Contract Choice and the California Gold Rush, 20 J.L. \& Econ. 421 (1977). 
complex relationships simply cannot realize their collective desire to minimize costs by relying exclusively on individual risk-bearing strategies.

One strong imphication follows from this analysis. We might well predict, contrary to the assumptions of the simple creditors' bargain inodel, that parties to a creditor's bargain would adopt a mixed strategy for bearing risk. Individualized strategies designed to reduce risk would generally be preferred, but some form of risk sharing would be adopted for those common perils that are too uncertain and interactive to make individual action ineaningful. ${ }^{24}$

\section{b. Risk Sharing as a Means of Diversifying Common Risks}

The assumption that creditors in an ex ante bargain unight well include a risk-sharing coinponent in their distribution scheme comphicates, to some extent, the clain that the value of nonbankruptcy entitleinents should be fully respected. Under a risk-sharing scheme, the theoretically optinnal priority relationship among various classes of claimants would not necessarily be simple and linear ( $A$ has priority over $B$ ), but rather would depend on the kind of risk that produced the business failure. Indeed, if default or insolvency could be causally linked to a common disaster, a pro rata sharing rule would be the optimal arrangement. Thus, it can no longer be fairly assuined that the ex ante bargain would grant secured creditors $100 \%$ of the value of their security in bankruptcy, for such an outcome assumes a binary risk assignment. Moreover, it can no longer be assumed that unsecured creditors were paid to assuine all of the risks of business failure in the initial extension of credit. This, too, assumes a binary risk assignment. Given that, it is significantly harder to determine which distributive results in bankruptcy conflict with the ex ante bargain and which distributive results actually inpleinent it.

It is one thing to assert that risk sharing might well be on the agenda at the creditors' bargain. It is quite another to be able to predict what form the sharing arrangement would take. Putting aside the important impleinentation probleins, however, consider the following story. Begin by visuahizing the risk-sharing agreement between secured and unsecured creditors as a form of prepaid insurance in which secured creditors would be paid in advance to potentially share a part of their assets in the future. ${ }^{25}$ Secured creditors would agree that whenever insolvency is triggered by common

24 See Scott, supra note 18 , at 2018.

25 This sharing agreement is the same, in principle, as any other contractual arrangement, such as a best efforts contract, in which a principal pays an agent in advance to look out for the principal's interests in the future. See Goetz \& Scott, Principles of Relational Contracts, 67 Va. L. Rev. 1089 (1981). 
risks (interrelated technological events with unpredictable effects) they would share with unsecured creditors and equity some of the asset pool otherwise reserved to them. Such an arrangement would provide a method of diversification for those risks that cannot be successfully reduced by individualized risk bearing.

To be sure, the bargaining creditors could choose imstead to diversify "internally" by extending credit with different degrees of risk to a number of debtors, thus building a risk-neutral portfolio. At least in theory, however, an "external" diversification, as represented by a risk-sharing scheine, nnay be a better means of diversification and thus may provide an optimal arrangement for some participants in the creditors' bargain. This argument seems particularly applicable to trade creditors and other unsecured claimants who may otherwise have limited opportumities to diversify. ${ }^{26}$

Once implementation costs are reintroduced into the analysis, the question recurs: How would the parties structure a risk-sharing scheme within the constraints of a broader system of imdividual risk bearing? Here again the relationship between bankruptcy and nonbankruptcy responses to business failure comes into sharper focus. Risk-sharing impulses are not peculiar to bankruptcy, but they may well be impossible to implement outside of bankruptcy. There are fornidable operational difficulties in distinguishing coininon risks from those that have been assigued to individual claimants. An attempt to do so on a case-by-case basis, whether inside or outside of bankruptcy, is likely to be excessively cumbersome. Thus, the absence of contractual mechanisms to do this sorting does not imply that the sorting is undesirable as a matter of theory. A prepaid imsurance scheme that effects a partial across the board reduction in the returns to secured creditors may be the only feasible implementation option. As long as the parties to the creditors' bargain are repeat players, such an insurance device is a simple forn of risk spreading more efficient than a case-by-case attempt to distinguish between contingencies that trigger either individualized or risk-sharing arrangements.

${ }^{26}$ It is tempting to argue that diversification through risk sharing is implausible where the claimants are repeat players because, in that context, the creditors would seem ideally suited for portfolio (or internal) diversification. To the contrary, however, the fact that claimants such as the trade creditors are repeat players does not alter a more powerful fact: trade creditors are likely to be heavily concentrated in particular industries (suppliers of lumber, for example) and are relatively incapable of adjusting for common risks affecting the industry by diversifying among different kinds of debtors or by altering risk with security arrangements. As long as a significant group of the participants in the ex ante bargain are thus rendered risk averse, a risk-sharing scheme will be a plausible strategy, even where other claimants are fully diversified and risk neutral. The risk-averse creditors will pay the others a premium for the privilege of diversification through risk sharing. 
From this follows an important point about bankruptcy's distributional rules. The fact that bankruptcy's distributional rules are distinct from those outside of bankruptcy does not justify the conclusion that bankruptcy's collective regime violates the creditors' bargain. Of course, neither does it follow that all "equal sharing" rules can be justified in bankruptcy either. If the collective proceeding deviates from the outcoine that would occur outside of bankruptcy, we must ask why the nonbankruptcy distributional systein did not adopt that risk-sharing outcome as well and how the sorting annong common and particular risks will be done in bankruptcy. We consider several of these questions later in this Article. For now, we simply make the point that an expanded creditors' bargain that takes account of the distinct nature of common risks can accommodate distributional changes in a collective proceeding such as bankruptcy.

\section{Eve of Bankruptcy Conflicts of Interest}

The problem of perverse incentives (or forum shopping) provides a powerful argument for preserving the value of prebankruptcy entitleinents in bankruptcy. It is important to remember, however, that perverse incentives are an inevitable consequence of any bankruptcy process. Any collectivizing procedure, even one that disinisses the risk-sharing point just explored, inevitably alters the prebankruptcy entitlements of individual participants. Pro rata sharing among general creditors, for exainple, is at best a crude approximation of relative values outside of bankruptcy. Even such a relatively uncontroversial rule ignores the fact that some claimants inay be better able to collect than others. Parties who anticipate losing the right to pursue individual methods of collection will, in turn, be motivated to pursue nonmaximizing objectives prior to bankruptcy.

Thus, any collectivization process generates inevitable conflicts of interest among claimants. ${ }^{27}$ These conflicts are especially severe on the eve.of bankruptcy. As the risk of busmess failure increases, an individual creditor is

27 Indeed, wholly apart from collectivization concerns, default rights themselves trigger conflicts of interest among claimants. An enterprise worth $\$ 80$ if sold and converted to cash today, but with a $50 \%$ chance of being worth $\$ 150$ and a $50 \%$ chance of being worth $\$ 50$ in a year's time faces a conflict of interest as between a creditor owed $\$ 90$ and an equity owner. Renegotiation will be necessary to preserve the going concern surplus of this company. Such conflicts exist because claimants with different priority claims to the assets have different perceptions of what to do with the assets. Any separation of decisionmaking power from the returns generated by that decision introduces this conflict, as a large body of agency literature demonstrates. See, e.g., A. Berle \& G. Means, The Modern Corporation and Private Property (1932); Fama, Agency Problems and the Theory of the Firm, 88 J. Pol. Econ. 288 (1980); Jensen \& Meckling, Theory of the Firm: Managerial Behavior, Agency Costs and Ownership Structure, 3 J. Fin. Econ. 305 (1976); Williamson, Managerial Discretion and Busmess Behavior, 53 Am. Econ. Rev. 1032 (1963). 
motivated to coerce the debtor to pay a greater share of its claim than that creditor would be able to recover in bankruptcy. This familiar problem underlies the preference rules of bankruptcy. By requiring creditors to disgorge payments received shortly before bankruptcy, the Bankruptcy Code reduces the incentives of creditors to engage in a mutually destructive race for the assets. ${ }^{28}$

As we will show, however, preference law is a necessary, but not a sufficient, condition for controlling eve of bankruptcy conflicts of interest. An additional conflict arises as a product of a general agency problem: those who have some control over a debtor's decisionmaking will have an incentive to make decisions that favor them, even if those decisions are harmful to the interests of the claimants as a group. Fraudulent conveyance law, along with a number of other legal rules, responds to the well-understood problems of inappropriate self-interested behavior by managers and equity. The problem appears agam in the bankruptcy timing decision. As previously noted, residual owners (such as equity) are likely to respond to insolvency by usmg delay tactics, even though delay may not be in the interest of the claimants as a group. One of bankruptcy's more vexing problemsensuring that bankruptcy proceedings start at the right time-arises out of this conflict.

A more subtle form of self-imterested behavior will occur among certain classes of secured creditors. These creditors, by contract, may have significant control over the decisionmaking apparatus of a firm teetering on insolvency. Here, the strategic behavior of secured creditors exercising control in the prebankruptcy period is to be distimguished from the destructive pursuit of individual interest once insolvency occurs. This problem of pre-insolvency strategic behavior is peculiarly acute in the case of small business debtors who are heavily dependent on general financing creditors with wraparound security imterests. These "relational" creditors have substantial leverage and thus de facto control over the business affairs of the debtor; they can (and do) influence the debtor's business decisions during the crucial period prior to insolvency and bankruptcy. ${ }^{29}$

Froin the perspective of the creditors as a group, it would be in the interest of all claimants that a relational creditor encourage only those financing and operational decisions that will maximize the expected value of the enter-

2811 U.S.C. $\$ 547$ (1982 \& Supp. IV 1986) (providing, inter alia, that payments made to a creditor within 90 days of bankruptcy by an insolvent debtor that enable the creditor to collect more than it would have collected in a liquidation procecding are voidable by the trustee as a preference). Although the objectives of preference law are clear, there is debate over whether $\S 547$ as drafted advances them. See McCoid, Bankruptcy, Preferences, and Efficiency: An Expression of Doubt, 67 Va. L. Rev. 249 (1981).

29 Scott, Relational Theory, supra note 4, at 916-22, 925-33, 944-52. 
prise. Given the inevitable distributional effects of bankruptcy, however, the relational creditor is motivated to solidify its priority position on the eve of bankruptcy, even if the resulting advantage operates to reduce the pool of assets available for general distribution. ${ }^{30}$

\section{a. The Analogy to General Average Contribution}

The phenomenon of eve of bankruptcy conflicts finds an analogue im the law of admiralty and the problem of general average contribution, which attempts to minimize agency problems associated with diverse ownership. ${ }^{31}$ The basic principle underlymg general averaging is that if a ship loaded with valuable cargo should founder at sea, the captam may make whatever sacrifices are necessary to prevent the ship and cargo from sinking altogether. All owners involved in the sail will contribute thereafter to the general average expense according to their percentage of ownership. ${ }^{32}$

Agency theory offers a persuasive justification for such a general average rule. The captain is the agent of all of the parties participating in the venture. When a perilous situation arises, it is $m$ the interest of all participants that the captain take all interests equally into account, affecting whatever sacrifice is necessary to promote the joint interests of all participants in the voyage. One method of approximating the cooperative result is to encourage the captain to act as if there were only one owner in the enterprise. If the ownership interests were integrated, it would not matter whose property were sacrificed, because all participants would bear the loss as joint venturers.

Under agency theory, therefore, the purpose of general average rules is to dissipate the captain's conflict between self-interest and duty at the moment of sacrifice. At that critical tine, the captain must decide if he should, for example, jettison the cargo or cut off the mast. Absent a sharing rule, a bias will necessarily invade the captain's judgment. The captain has an obvious interest in preserving the ship for the benefit of the owner, his employer. Moreover, if the captain jettisons the cargo, the adversely affected cargo owners will predictably claim that the captain overlooked a less costly method of sacrifice. Consequently, the captain is also inotivated to minimize

30 Preference law will catch some, but not necessarily all, of this strategic behavior. A rule such as $\S 547(\mathrm{c})(5)$, for example, can be used to avoid an absolute improvement in the creditor's position on the eve of bankruptcy. But the secured creditor's position may not have improved in absolute terms, although it may have improved in relative terms, due to the secured creditor's access to decisionmaking controls. See 11 U.S.C. $\S 547(c)(5)$ (Supp. IV 1986).

31 The analogy to general average contribution builds on the discussion in Scott, Through Bankruptcy, supra note 4 , at 700-07.

32 See G. Gilmore \& C. Black, The Law of Admiralty 244 (2d ed. 1975). 
any subsequent claims that his judgments were flawed. If the captain's conflicting interests are sufficiently strong at the moinent of crisis, he will inake jettison decisions that are inconsistent with the joint interests of the parties. The rule requiring a general average contribution encourages the captain to make the inost efficient jettison possible.

Clainants in the creditors' bargain can predict that analogous events may occur on the eve of bankruptcy. The threat of a business failure owing to coinplex and interactive contingencies (such as the effects of the stock market collapse on supply and demand conditions in a particular industry) inay be seen as a common risk that, despite individual efforts, will inevitably occur unless creditors agree to sacrifice a portion of their clain in order to save the enterprise. On the other hand, the normal risks of business failure are not common risks, and the interests that sustain the loss inust bear it alone. ${ }^{33}$ This is true in the admiralty analogue as well. There is no right of general average contribution in the ordinary case of loss or marine inishap. ${ }^{34}$ Before any of the affected interests has a right to a general average contribution, three requirements must be met. First, there inust be a common danger $^{35}$ that will cause inevitable losses unless a portion of the whole is sacrificed to save the remainder. Second, in an attempt to avoid the peril, part of the ship or cargo must be jettisoned. ${ }^{36}$ Third, the attempt to avoid the coininon peril must be successful. ${ }^{37}$ Thus, by analogy, eve of bankruptcy contribution requires both a comnnon peril and a sacrifice of individual rights in order to rehabilitate the enterprise.

Anticipating these conditions, the parties to the creditors' bargaim would seek to avoid self-interested bias whenever such "jettison" decisions must be made. In the bankruptcy analogue to general average contribution, a doimnant secured creditor-such as a general financing bank-is equivalent to the ship's captain struggling to save the vessel in high seas. The dominant secured creditor is pecuharly able to influence the course of events prior to insolvency in such a way that its ultimate self-interest may be advanced.

33 This point provides a bridge to the hiterature on the efficiencies of differentiated capital structures (such as secured credit). "Equal sharing" rules vis-a-vis all kinds of risks would undermine the need for secured credit in the first place. See supra note 13.

34 See G. Gilmore \& C. Black, supra note 32, at 246. Any loss so regarded is designated as a "particular" average. The owner who suffers such a loss inay have a right of indemnity, but there is no right of contribution based on general average.

35 The necessary and sufficient conditions for these common risks are analyzed in Part I.B.1.a., see supra notes 18-24 and accompanying text. The concept of "coininon danger" is defined in maritime law as "a danger in which ship, cargo, and crew all participate; a danger iınıninent and apparently 'inevitable." " Barnard v. Adams, 51 U.S. (10 How.) 270, 303 (1850).

36 Barnard, 51 U.S. (10 How.) at 303.

37 Id.; Cia. Atlantica Pacifica, S.A. v. Humble Oil \& Refining Co., 274 F. Supp. 884, 889 (D. Md. 1967). 
The interests of the owners as a group (secured creditors, unsecured creditors, and equity) are advanced, however, only if the dominant secured creditor acts as if it were the sole owner. Some form of sharing rule may promote that cooperative behavior.

\section{b. Risk Sharing as a Means of Bankruptcy Contribution}

The preceding analysis suggests that participants in the ex ante bargain would agree to coutribution in bankruptcy so as to eucourage an optimal prebankruptcy jettison of some of the debtor's assets and liabilities. ${ }^{38}$ Ideally, of course, the sacrifice would serve to avoid entirely the cominon peril that threatens to trigger insolvency. In many instances, however, because insolvency and business failure are not necessarily linked, the protective umbrella of bankruptcy reorganization will be necessary to achieve successful rehabilitation of the enterprise. In such cases, the willingness of claimants to sacrifice some of their entitlenients in the prebankruptcy period may improve the prospects for a successful rehabilitation and increase the expected value of the firm. Of course, the sacrifice nuust occur before insolvency, and the decision as to which portion of the debtor's assets or liabilities is to be sacrificed will largely rest with the general financing secured creditor. Thus, the right to a general average-type contribution if bankruptcy results is a necessary inducennent to secure the cooperation of all creditors.

38 The familiar problem known as "feeding the lien" provides a good example of the selfinterested behavior that inay attend prebankruptcy decisionmaking. Suppose that Secured Creditor has a security interest in all Debtor's presently held and after-acquired accounts and that unanticipated circnmstances liave left Debtor with inadcquate cash reserves to service its debt and insufficient accounts to cover the secured loan. A sale of assets is thus necessary to generate the cash to keep the business solvent. Assume further that Debtor must deeide whether to sell off used equipinent or discount inventory in order to effect the needed jettison, and that the value-maximizing choice is to sell the equipment for cash. Notwitlstanding these considerations, Seeured Creditor has an ineentive to exercise the leverage that its floating lien provides to induce the debtor to deelare a "fire sale" and dispose of the inventory at discount prices. Such an action will serve two purposes: it will generate needed cash, and it will generate the accounts necessary to increase the inargin of security for Seeured Creditor.

Obviously, it is in the interests of all parties that this potential conflict be reduced through the terms of the ex ante bargain. Preference law is, by itself, inadequate to encourage Secured Creditor to support the value-maximizing choice. First, this transfer may be inade prior to the 90-day period provided by $\S 547$. Second, even if the transfer is within 90 days of the bankruptcy petition, it will be invulnerable under $\S 547(\mathrm{c})(5)$, so long as Secured Creditor's miprovement is only relative and not absolute. See supra note 30 .

The effect of a sharing rule such as bankruptcy contribution is to moderate the returns froin self-interested behavior. If Secured Creditor encourages the inefficient option and Debtor lands in bankruptcy, Secured Creditor must share with the other claimants sone of the gains from "feeding the lien." By reducing the benefits of self-interested action, a contribution rule enhances the prospect of optimal cooperative behavior. 
The conditions that make contribution an attractive solution to conflicts of interest between claimants are not peculiar to bankruptcy. It is important to see, however, that these conflicts are peculiarly linked to the collectivization problem that provides the normative justification for bankruptcy under the simple creditors' bargain vision. Thus, to the extent that the creditors in the ex ante bargain determine to collectivize in order to solve a central problem of noncooperation, they would necessarily agree to a contribution arrangement in order to restrain eve of bankruptcy conflicts. In the absence of bankruptcy contribution, the parties would anticipate inefficient jettisons by secured creditors' exercising de facto control over the debtor's business decisionmaking. Because such inefficiencies reduce total creditor wealth, contribution would be a predictable prophylactic to any collectivization process.

The parties to the ex ante bargain would also weigh the problems of implementing a contribution scheme prior to reaching agreement on specific procedures. Obviously, a general average-type contribution that is triggered only if bankruptcy proceedings are instituted exacerbates the problem of perverse incentives. This does not imply, however, that the parties would not agree on a contribution rule. The presence of perverse incentives is clearly a cost. Whether it would outweigh any resultimg benefits remains an empirical question.

\section{The Valuation Dilemma: The Problem Of Firm-Specific Capital Investments}

The simple creditors' bargain model makes the further assumption that the efforts of all claimants $m$ the ex ante bargain are directed towards maximizing group welfare as measured im monetary or other objective terms. At first glance this seems unproblematic. The value of an ordinary busmess firm is based on a standard assumption of profit maximization. Yet a number of firms facing bankruptcy do not comfortably fit this paradigm. For exanple, small, closely held firms, particularly those in which a single owner-manger has the equity imterest, may be better described as a mix of objective and idiosyncratic values. At least for some of these firms, the owner-manager will anticipate making substantial nonpecumary or sentimental investments during the life of the enterprise. These investments are reflected in common metaphors such as "It's my life's work," and "My name is over the door."39 Furthermore, an owner-manager's firm-specific

39 The anecdotal character of the common metaphors for firm-specific investment suggest how difficult these investments are to characterize, much less to measure. Nevertheless, few would argue with the proposition that owner-managers inake capital investments in their enterprises that are not entirely valued in money or money's worth. 
investınent is essentially nondiversifiable. Thus, a risk-averse entrepreneur may bear a degree of risk that, absent other forms of risk reduction, leaves him with a suboptimal return.

How might the creditors' bargain differ if the assumption of objective valuation is relaxed? Assume initially that any bargain the parties strike can be costlessly implemented. Under these conditions, debtors who anticipate Inaking substantial firm-specific capital investnents in their enterprises would be willing to buy additional "insurance" coverage to protect the investnients. In theory, this insurance protection could be provided in several different ways. But standard options such as monetary paynients would be subject to noral hazard and false claims. A less costly alternative would be to offer the equity interest a more generous opportunity for rehabilitation. This form of prepaid insurance would reduce the risk of hquidation induced by the fact that, but for the idiosyncratic value, the insolvent firm may be worth nore dead than ahive.

The evidence that idiosyncratic value is not easily protected through third-party insurance buttresses the assumption that parties who anticipate such investments can insure inost efficiently by nodifying the terms of the ex ante bargain itself. ${ }^{40}$ This built-in insurance coverage is thus a form of risk sharing of the type we have previously exanined. For instance, the bargainers might agree to reduce the payments to secured creditors or to restrain foreclosure on collateral whenever these measures would improve marginally the prospect of rehabilitation. It is iniportant to emphasize that this argument assumes that the owner-manager who conteniplates idiosyncratic investments would be interested only in purchasing a greater chance for rehabilitation of the enterprise. In other words, firm-specific investnients impel a form of reorganization insurance, but not insurance against liquidation under all circumstances.

This analysis, however, is not by itself sufficient to justify a sharing rule between equity interests and creditors in bankruptcy. Even if we have described a "deserving" class of equity clainiants, on what basis can this group be distinguished from others-those, for exainple, who are fully diversified-who would not pay to insure against the loss of idiosyncratic value? Moreover, any systeni attenipting to implement such an insurance schenie faces a further sorting probleni. Legitimate clainis of protection against the destruction of idiosyncratic value will be hard to distinguish from illegitiinate claims, such as where the equity owner's inconipetence or inisnianagenient is the cause of the firm's problems.

40 See Goetz \& Scott, Liquidated Damages, Penalties and the Just Compensation Principle: Some Notes on an Enforcement Model and a Theory of Efficient Breach, 77 Colum. L. Rev. $554,578-83$ (1977). 
For these reasons, it is tempting to argue that nonbankruptcy alternatives, especially ordinary contractual mechanisnis, are the optimal means of structuring such a complex insurance scheme. If equity owners wish their creditors to offer a form of reorganization insurance, it would be possible to design contracts that provided such msurance without resort to bankruptcy. In other words, the analysis may prove too much. If firm-specific value is unprotected, reorganization insurance should be written generally or should be imphied in nonbankruptcy rules governing default and foreclosure.

It may be, however, that collective action problems in an individual collection regime are so paralyzing that no single creditor would agree to a form of reorganization imsurance without a guaranty that all other creditors would also abide by the rules. Enforcement problems outside bankruptcy may mean that contractual options would not be available, even if reorganization imsurance was otherwise desirable. A collective solution such as bankruptcy may be the only place to determine whether the imsurance payout is appropriate im a particular case. ${ }^{41}$

Any such result means that one outcome prevails outside of bankruptcy and another prevails mside of bankruptcy. Owner-managers may resort to bankruptcy simply to secure the reorganization insurance, even if they were not otherwise entitled to it. Transition costs and implementation problems may swamp any gains otherwise to be made by such a scheme. The limiting focus of Chapter 11 reorganizations, however, seems to provide a useful method of screening for those debtors with an idiosyncratic capital investment. The best case for a distmct reorganization process is where many claimants have made difficult-to-value investinents in the debtor firm sufficient to deter third-party purchases of the business as an entity in any hiquidation process. If so, then it is precisely the firms suited for reorganization that are also likely to have equity interests that require supplemental protection.

41 Bankruptcy courts traditionally look with hostility on cases where the debtor has (essentially) only one creditor. See supra note 11 . Under a simple creditors' bargain analysis, this skepticism is normatively appropriate, as it implies the absence of a collective action problem among claimants of the same group and instead reflects simply the result of the original distribution of entitlements. The question of firm-specific investments, however, may offer a different perspective on one-creditor bankruptcy cases. The issue becomes whether the contract between the equity and the sole creditor should have reflected explicitly the reorganization insurance. At lcast in cases where the one creditor did not expect to be the sole creditor under all circumstances, the discussion in the text suggests that the parties may have implicitly agreed to a form of reorgamization insurance in bankruptcy. 


\section{Nonconsensual Distributional Effects}

Regardless of the ex ante agreement, any bankruptcy system will inevitably be subject to random or unsystematic distributional effects. Ad hoc distributions may result from misinterpretations of the appropriate policies by decisionmakers or from successful efforts by individual claimants to secure a disproportionate share of the asset pool. They may also result from attempts to decide relative value issues by usmg fairly crude rules of thumb. These effects are some of the mipleinentation costs that will influence the extent to which the objectives of the bargainers can be realized.

More interesting than these unsystematic effects, lowever, are distributions to third parties who would not fairly be considered participants in a creditors' bargain. These nonparticipating parties might include nonconsensual interests such as tort claimants, residents of the community im which the business is located, or any others affected by the liquidation of busmess enterprises.

In some sense, these claimants are analogous to the victims of a common disaster, such as a flood. When a community is devastated by flooding, a state of einergency is frequently declared, and the victims are assisted witl public funds. It is quite appropriate for the state to respond when these catastroplies are unavoidable. It is curious, though, that we are also willing to assist when the disaster is foreseeable, as $\mathrm{m}$ the case of individuals who choose to reinain in the flood plain. ${ }^{42}$ Similarly, tort claimants, retired einployees, residents of the community, and other affected third parties miglit well be considered "victims" of business failure and bankruptcy. It is true that these parties make choices about where to work, witl which firms to deal, and wliat purcliases to make. Yet these parties share an important quality with the victims of true disasters that may explain why all such victiins are the beneficiaries of distributions when catastrophe strikes. It is possible that people who live in flood plains, as well as the unsophisticated claimants who interact witl business firms, have no real clioice. That is, they cannot rely on risk-reducing alternatives such as insurance, security, or otler bonding mecliamisms. Because these parties do not have an opportunity to protect theinselves with security, it can be argued that they "deserve" a distribution of the assets in bankruptcy in the same way that flood victims deserve assistance. ${ }^{43}$

It is not our goal in this Article to assess the normative appeal of this

42 Presumably, where the risks of flooding are known, affected parties could move to a safer location or insure against the knowable risks of flooding. The government subsidy reduces their incentives to do so. Scott, Relational Theory, supra note 4, at 968 n.247.

43 Id.; Note, supra note 12, at 1508 . 
vision. ${ }^{44}$ For our purposes here, it is important only to see that whatever the merits of the claim that society owes such victims protection against disaster, this protection does not derive from the consensual arrangements that would underhie any ex ante creditors' bargain. Distributions to nonconsensual claimants are conceptually different from those that would be agreed to im any bargain in which imdividual self-imterest was a central feature. In fact, it may im some sense be analytically correct to suggest that the problems that animate distribution to nonconsensual victims of common disasters are not "bankruptcy" problems. ${ }^{45}$ To be sure, the individual participants in the creditors' bargain would presumably be as willing to support these claimants as they would any other charitable cause. From the perspective of the collective, however, these forms of redistribution will be seen as costs of bankruptcy that will undermine, at least in part, the primary objectives of collectivization.

It is not similarly correct, however, to characterize as bankruptcy costs those distributions that might well be approved in the ex ante bargain. As the preceding discussion shows, these "approved" distributions are part of the benefits of a bankruptcy process in the very same sense that collectivization in the first instance is a benefit of bankruptcy. They are, at least in theory, an integral feature of any separate bankruptcy procedure that trumps the existing mechanism of debt collection and distribution.

\section{APPlying the Model: AN ANALysis of the Distributional EFFECTS OF BANKRUPTCY}

The common disaster formulation adds additional complexity to the creditors' bargam model. Such complexity is not mherently desirable. Indeed,

44 For a detailed analysis of these questions in light of the particular problem of utility regulation and bankruptcy, see Eisenberg, Bankruptcy in the Admimistrative State, Law \& Contemp. Probs., Spring 1987, at 3; see also Roe, Bankruptcy and Mass Tort, 84 Colum. L. Rev. 846 (1984) (current bankruptcy law shortchanges future tort claimants, so Bankruptcy Code slould be changed to give sucl claimants reorganization initiation powers).

45 For example, society generally treats tort victims differently from employees and residents of a community. Under nost forms of legal rules in existence today, tort victims have "clainus" to a debtor's assets, whereas residents of a town do not. Firms, whether in default or not, can move from a town, despite the objections of its residents. Firms caunot likewise leave tort problems behind. Moreover, tort victims generally share as unsecured creditors, having few opportunities to secure their claims. See Schwartz, Products Liability, Corporate Structure, and Bankruptcy: Toxic Substances and the Remote Risk Relationship, 14 J. Legal Stud. 689 (1985); Note, Tort Creditor Priority in the Secured Credit System: Asbestos Times, the Worst of Times, 36 Stan. L. Rev. 1045 (1984). State law may provide tort victims with a statutory lien. See, e.g., N.J. Stat. Ann. § 58:10-23:11f(f) (West Supp. 1988) (lien filed by the Administrator of the New Jersey Spill Compensation Fund against the property of a debtor that is subject to a cleanup order lias priority over all other claims or liens). 
the test of any model is whether it better predicts or explains observed features of the bankruptcy process. Testing the enriched inodel is not easy. As a preliminary effort, we have cliosen three proininent features of the bankruptcy process in which distributional effects are commonly observed: (1) the powers of the bankruptcy trustee to enhance tlie estate; (2) the timevalue calculation required to reimburse secured creditors for delay costs; and (3) the impleinentation of Chapter 11 reorganization plans. We now consider whether a richer version of the creditors' bargain better explains the apparent tensions that mark these features of federal bankruptcy law.

\section{A. The Trustee's Collection Powers}

\section{The Strong-arm Power of Section 544(a)}

The operation of the so-called strong-arm clause of section 544(a) of tlie Bankruptcy Code offers a classic illustration of the distributional effects of bankruptcy. ${ }^{46}$ Assuine, for example, that a creditor (C1) lends Debtor $\$ 50,000$ on May 1 and in return takes a security interest in inventory and equipment, but does not file a financing stateinent. On May 5, a trade creditor (C2) lends Debtor $\$ 50,000$ on open account. Five days later Debtor files a petition in bankruptcy. In a contest between $\mathrm{Cl}$ and the trustee in bankruptcy, the trustee can avoid the $\$ 50,000$ security interest under section 544(a)(1), even thougli no otlier creditor has acquired a lien against the assets. This has the effect of bringing tle debtor's inventory and equipment covered by the security interest into the estate for pro rata distribution to $\mathrm{C} 1, \mathrm{C} 2$, and other general creditors.

The conventional justification for the strong-arm clause is that it promotes the equality norm. This inetaphor is unhelpful by itself, however, because one needs to know equal relative to what. Secured creditors are certainly not treated "equally" with equity im bankruptcy, even after application of section 544(a). The simple creditors' bargain explanation attempts to cure this defect in the conventional justification. It posits that the normatively desirable effect of section 544(a) is to implenent tlie collective proceeding by freezing prebankruptcy entitleinents. In other words, tlie strong-arm rule ensures that those similarly situated outside of bankruptcy will be treated equally in bankruptcy. On May 10th, neither $\mathrm{Cl}$ nor $\mathrm{C} 2$ lias taken the ultimate step to assure its priority over the other, eitler by a filing or a judginent hen. Thius, in a collective proceeding, they are in a position of equality.

46 Section 544(a) grants to the bankruptcy trustee the status of a judicial lien creditor from the date of the commencement of the case, whether or not sucl a creditor actually exists. See 11 U.S.C. § 544(a) (1982 \& Supp. IV 1986). Under § 544(a) of the Bankruptcy Code and § 9301(1)(b) of the Uniform Commercial Code, U.C.C. $\$ 9-301(1)(b)$ (1987), the trustee in bankruptcy obtains priority over an unperfected security interest existing on the date of filing. 
But this story by itself is not entirely convincing. In a contest under state law between $\mathrm{Cl}$ and $\mathrm{C} 2$ on May 10th, $\mathrm{C} 1$ would prevail by the terms of the Uniform Commercial Code's section 9-201. ${ }^{47}$ Section 544(a) cannot, therefore, be seen simply as a provision preserving the relative positions of the parties as they move from state law into bankruptcy. Instead, it has a distinct distributional effect. The simple creditors' bargain explanation responds accordingly by changing the focus to relative value. To be sure, $\mathrm{Cl}$ would prevail on May 10 if nothing more happened. Because the bankruptcy filing ensures that nothing more will happen, one needs to predict what would happen had bankruptcy not intervened. Because this outcome is indeterminate, the best one can do is to treat $\mathrm{C} 1$ and $\mathrm{C} 2$ as relative equals, the result of section $544(a){ }^{48}$

This explanation, however, does not avoid the distributional change that section 544(a) makes in the nonbankruptcy entitlements. Instead, it assumes that, for the sake of convenience, it is easier to presume a pro rata sharmg rule for all unsecured and unperfected secured creditors than it is to look into the highly individualistic features of each creditor (whether unsecured or unperfected) to see which creditor, in fact, was more likely to "win the nonbankruptcy race." According to that explanation, convenience ultimately lies behind the selection imposed by section 544(a).

Are any further insights offered by the expanded creditors' bargain vision of bankruptcy? A common disaster explanation for section 544(a) rehes on the impulse to effect general average-type contribution im bankruptcy. Recall that under this conception a dominant secured creditor is analogous to the captain of the ship who earns an additional preinium for successfully negotiating the enterprise through perils. As a necessary corollary, the group must ensure that these leadership decisions are consistent with the interest of the collective. Information concerning the special relationship between debtor and secured party is necessary if the group is to monitor the secured creditor effectively. In the above exainple, the secured creditor, by failing to file a finance statement, did not disclose key information important to the collective interests of all creditors. The secured creditor thus forfeits its right to the prenium return and is treated as any other meniber of the group.

In short, under this richer version of the creditors' bargain, section 544(a) is not an equalizing rule as much as it is a leveling rule. It is a necessary

47 U.C.C. $\$ 9-201$ (1987) provides that "except as otherwise provided by this Act a security agreement is effective according to its terms ... against creditors." Because no other provision of U.C.C. Article 9 subordinates $\mathrm{Cl}$ to $\mathrm{C} 2, \mathrm{C1}$ would prevail under this section. See $\mathrm{McC}$ Coid, Bankruptcy, The Avoiding Powers, and Unperfected Security Interests, 59 Am. Bankr. L.J. 175,188 (1985).

48 T. Jackson, supra note 1 , at $70-79$. 
prophylactic to ensure cooperative behavior by powerful creditors in the critical period prior to bankruptcy. ${ }^{49}$ The sanction of relegating the secured creditor to the ranks of all other claimants supports the general pohicy of restraining eve of bankruptcy conflicts when "jettison" decisions are being nade.

The preceding argument suggests that several explanations for rules such as section 544(a) are both possible and plausible. We do not mean to choose here among these explanations. It is perfectly possible that one would need to combine both explanations in order fully to understand the rule. For example, the common disaster vision of section 544(a) focuses on security interests that could have been publicly noted, but were not. Yet, numerous statutory hens are accorded priority under section 545 , irrespective of the fact that they are not publicly noted. ${ }^{50}$ Thus, one needs to distimguish between consensual liens (subject to section 544(a)) and statutory liens, perhaps on the ground that only with the former is there a prospect of a doininant secured creditor that may have significant control in the prebankruptcy period. In short, the choice among these or any other competing explanations ultimately rests on the accumulated evidence of the actual operation of bankruptcy avoidance powers in particular cases.

\section{Moore v. Bay and Section 544(b)}

Section $544(b)^{51}$ and the rule of Moore v. Bay ${ }^{52}$ provide an even more dramatic illustration of a similar distributional effect. Although the reach of section $544(b)$ is now significantly limited under the new Code, ${ }^{53}$ it reinforces the deterrent effects of the trustee's avoidance powers. Imagine the

49 This view of $\S 544$ (a) looks only to the equalizing of the unperfected secured creditor with the unsecured creditor. As for why a pro rata sharing rule is used among unsecured creditors, one inay have to rely on the superiority of an equal sharing rule as an ex ante solution to an ex post distribution.

so 11 U.S.C. § 545 (1982); see, e.g., California v. Farmers Mkts., Inc. (In re Farmers Mkts., Inc.), 792 F.2d. 1400 (9th Cir. 1986); Artus v. Alaska Dep't of Labor, Einployment Sec. Div. (In re Anchorage Int'l Inn), 718 F.2d. 1446 (9th Cir. 1983). See generally Jackson, Statutory Liens and Constructive Trusts im Bankruptcy: Undoing the Confusion, 61 Am. Bankr. L.J. 287 (1987) (suggesting status test should be that if interest is effective outside of bankruptcy, then it is effective inside bankruptcy as well).

si 11 U.S.C. § 544(b) (Supp. IV 1986) (the trustee may avoid any transfer of the debtor's property that is voidable under nonbankruptcy law by any unsecured creditor who holds a claim against the estate).

52284 U.S. 4, 5 (1931) ("[C]laims which for want of record or for other reasons would not have been valid hens as agamst the claims of the creditors of the bankrupt shall not be liens against his estate."). This has been interpreted to inean that a transfer that is invalid as against one creditor ean be avoided totally by the trustee.

53 See S. Rep. No. 989, 95th Cong., 2d Sess. 85, reprinted in 1978 U.S. Code Cong. \& Admin. News 5787, 5871. 
followimg scenario. On June 1, 1986, C1 lends a manager of Debtor $\$ 1$ million as part of a leveraged buyout in which the manager is acquiring the common stock of Debtor. In return, $\mathrm{C} 1$ takes a security interest from Debtor in all of the firm's mventory and equipment, which is valued at over $\$ 1$ million. At the time of the transaction, Debtor already owed C2, a trade creditor, $\$ 3000$ on open account. If Debtor files for bankruptcy on July 1, 1987, can the trustee successfully avoid any or all of the security interest held by $\mathrm{Cl}$ ?

The arrangement between $\mathrm{Cl}$ and Debtor may be vulnerable as a fraudulent conveyance on several grounds. First, the trustee may argue that the security interest was a transfer made witl actual intent to hinder creditors by imperiling the general creditors' claims against Debtor. ${ }^{54}$ The close relationship between Debtor and manager may supply the "badge of fraud" that supports a presumption of actual intent.

Moreover, the doctrine of constructive fraud offers a further argument when combined witli an analysis that collapses the two transactions. Viewed as discrete transactions, the transfer of the security imterest from Debtor to $\mathrm{C} 1$ was for fair consideration (in excliange for the \$1 million loan). Once the two transactions are collapsed, however, the effect is that $\mathrm{Cl}$ gave $\$ 1$ million to the manager witl Debtor picking up the tab..$^{55} \mathrm{~A}$ court may decide to pursue $\mathrm{C} 1$ on the ground that, because $\mathrm{C} 1 \mathrm{knew}$ the money would go to the manager, it really did not give value to Debtor. Although $\mathrm{C} 1$ did not "get something for notling," one can conclude, on "gatekeepmg" grounds, that a fraudulent conveyance action is appropriate against $\mathrm{Cl}$ (witl $\mathrm{Cl}$ then succeeding to the action against the manager as the ultimate beneficiary of the conveyance). Under this conception, the transfer of a security interest by Debtor to guarantee the loan to the acquiring manager was given witlout fair consideration and, in this case, rendered Debtor insolvent. Thus, the transfer of the security interest to $\mathrm{C} 1$ may also be void as agamst $\mathrm{C2}$, the preexistimg creditor, under the state's fraudulent conveyance law. ${ }^{56}$

54 See Unif. Fraudulent Conveyance Act § 7, 7A U.L.A. 509 (1985); Unif. Fraudulent Transfer Act $\S 4(a)(1), 7 A$ U.L.A. 652 (1985).

55 The transaction is identical to a case where $\mathrm{C} 1$ lends Debtor money and the money is then given to Manager (or the old shareholders) in a pre- or post-buyout dividend. As constructed, and unless Manager can advance a synergy argument, Manager (or the old shareholders) received a transfer from Debtor without giving fair consideration. For that reason, a recovery against Manager (or the old shareholders) on fraudulent conveyance grounds seems plausible. See Jackson, The Continuing Life of Dcan v. Davis, 1988 Ann. Surv. of Bankr. L. 63.

56 Id. at 70-73. Section 4 of the Uniform Fraudulent Conveyance Act (UFCA), which was adopted in over 30 states, Unif. Fraudulent Conveyance Act, 7A U.L.A. 427 (1985), provides that a transfer niade without fair consideration that renders the debtor insolvent is void as to 
Because the transfer occurred more than one year before bankruptcy, the trustee cannot proceed under section 548 of the Bankruptcy Code to avoid C1's security interest. ${ }^{57}$ The trustee may instead use C2's state law claim against $\mathrm{C} 1$ to avoid the transfer under section 544(b). What makes section 544(b) unique is that it incorporates the rule of Moore v. Bay. By using this provision, the trustee is not limited to the $\$ 3000$ claim of $\mathrm{C} 2$ but can avoid the entire $\$ 1$ million security interest claimed by $\mathrm{Cl}$ and then retain the entire value of the debtor's inventory and equipment for the benefit of all the general creditors. Viewed through the lens of the simple creditors' bargain model, the effect of section $544(\mathrm{~b})$ is to redistribute assets beyond the requirements of collectivization, thus exacerbating perverse incentive problems. $^{58}$

Does the expanded creditors' bargain provide a rationale for section 544(b) and for the rule of Moore v. Bay? Clearly, section 544(b) operates to punish the secured creditor. It is not so clear, however, why the sanction is so severe and furthermore why the distributional effect extends to all creditors, not just to those who actively extended credit prior to the fraudulent transfer. The answers to these questions may, once agam, be traced to the collective concern for ameliorating conflicts on the eve of bankruptcy. In this case, by hypothesis, $\mathrm{Cl}$ has misbehaved. ${ }^{59}$ Given the dominant position of the secured creditor, the cost of detecting such misbehavior is hikely to be extremely high. A leveraged buyout may have either benign or malignant purposes. The malign scenario is that under the guise of a value-maximizing transaction certain creditors are exploited im a one-shot transfer that is hard to pohice. Because monitoring is so difficult, in the absence of legal sanctions other exploitable creditors would make suboptimal efforts to detect the fraud. If the probability of detection of a malignant buyout is less than 1.0, the effective sanction can be raised by imcreasing the nominal sanction in those cases where the transaction is determined to violate the interests of the

existing creditors. Id. at 474 . The UFCA is increasingly being replaced by the Uniform Fraudulent Transfer Act. Id. at 88 (Supp. 1988).

57 Bankruptcy Code $\S 548(a)(1)$ provides that the trustee may avoid a transfer of debtor's property made within one year of the filing, if the debtor received less than fair value and was or became insolvent, having unreasonably small capital to engage in business and repay anticipated debts. See 11 U.S.C. $\S 548$ (a)(1) (1982 \& Supp. IV 1986). A similar result would prevail under $\S 5$ (a) of the newly promulgated Uniform Fraudulent Transfer Act. See Umif. Fraudulent Transfer Act § 5(a), 7A U.L.A. 657 (1985).

58 But see Eisenberg, A Bankruptcy Machine That Would Go of Itself, 39 Stan. L. Rev. $1519,1530-32$ (1987) ("[N] perfect natching of the likely nonbankruptcy state law result can occur. Moore therefore cannot be dismissed for failing to provide such a match.").

59 Actually $\mathrm{Cl}$ has misbehaved only if one imposes a policing duty on it: the misbehavior in the first instance is that of the manager. 
collective. $^{60}$

This argument, however, does not explain why the Moore v. Bay rufe is applied only in bankruptcy, but not im fraudulent conveyance law generally. ${ }^{61}$ Other considerations do suggest, however, that implementation problems aside, liniting this rule to bankruptcy is optimal. One obvious problem with implementing the rule of Moore $v$. Bay outside of bankruptcy is that a single creditor who sues to set aside the fraudulent conveyance will benefit from avoidance of the entire transfer. Such a "bounty" outside of a collective regime may induce undesirable behavior. The harmful effects of bounty huntimg could be obviated, or at least reduced, if the remedy were available only to the creditors as a group and only where the recovery would be spread anong all the creditors.

\section{Executory Contracts under Section 365 and Loan Reinstatement under Section 1124}

The avoidance powers of section 544, together with the preference rules of section 547,62 can be seen as methods of encouraging individual creditors to behave cooperatively in the period just before bankruptcy. These provisions redistribute assets in order to amehorate anticipated conflicts between selfinterest and collective responsibility. Certain other rules, however, require a different rationalization. Under section 365, the trustee can either assume or reject executory contracts of the debtor. ${ }^{63}$ The rejection of an executory

60 Under this analysis, $\$ 544(\mathrm{~b})$ may be too narrow in other respects. Section $544(\mathrm{~b})$ is generally considered to give a trustee only the avoidance powers of unsecured creditors, not the creditors' rights as to damages. See Mixon v. Anderson (In re Ozark Restaurant Equip. Co.), 816 F.2d 1222 (8th Cir.), cert. denied sub nom. Jacoway v. Anderson, 108 S. Ct. 147 (1987); cf. Caplin v. Marine Midland Grace Trust Co., 406 U.S. 416 (1972) (result under prior law). Thus, for example, U.C.C. $\S 6-104$ (1987) currently provides creditors with a power to avoid defective bulk transfers-a power available to the trustee under $\S 544(\mathrm{~b})$. But the proposed revision of Article 6 will change the remedy to a damage action and, as currently interpreted, a $\S 544(b)$ action will no longer be available to the trustee. See Hawkland, Proposed Revisions to U.C.C. Article 6, 38 Bus. Law. 1729, 1745 (1983). Why $\S 544$ (b) so limits the trustee's powers is not clear. See Letter from Frank Kennedy to Joel Zweibel (March 9, 1988) (copy on file with Virginia Law Review Association) ("If the creditors of a seller can recover the amount of their claims from a noncomplying buyer, a bankruptcy court may view the result as in substance and effeet an avoidance of the bulk transfer.").

61 Moreover, because $\$ 544(b)$ - and hence the reach of Moore-is not limited to fraudulent conveyance rules, it is unclear whether the deterrence-type argument we have sketched in the text for fraudulent conveyance law would necessarily apply with equal validity to other apphications of Moore, such as in the case of violations of bulk sales laws.

6211 U.S.C. $\$ 547$ (1982 \& Supp. IV 1986).

63 Id. $\$ 365$ (a) (" $[T]$ he trustee ... may assume or rejeet any executory contract or unexpired lease of the debtor."). The standard definition of an executory contract can be found in the legislative history to $\S 365$. See H.R. Rep. No. 595, 95th Cong., 1st Sess. 347, reprinted in 1978 U.S. Code Cong. \& Admin. News 5963, 6303 (1977) ("It generally mcludes contracts on 
obligation has the same effect as does any other unpaid claim. Because bankruptcy is a contractual breach, it relegates the contract holder to the status of a general creditor. The executory contract also entitles the debtor to a return performance. Thus, the contractual obligation is an asset as well as a hability. The same effect nay occur in the case of unpaid loans. Whereas an unpaid loan is usually considered a liability in bankruptcy, there are situations where it is an asset as well-such as where the loan is both fully secured and below-inarket at the time of bankruptcy. In those cases, the debtor would rather use the primcipal than repay the creditor in full.

As a result, there may be cases where the debtor wishes to "assume" the asset reflected in a favorable executory contract or'below-market loan. Both section 365(b) and section 1124(2) permit this, notwithstanding defaults or the advent of bankruptcy, as long as any substantive defaults are cured. ${ }^{64}$ The simple creditors' bargain explanation for these provisions focuses on the change of ownership reflected in bankruptcy, where the creditors supplant the old equity owners. Thus conceived, these rules support the collective interest by reinstating obligations breached by the equity owners in the immediate prebankruptcy period, at a time when the equity owners did not necessarily have the interests of the collective in mind.

The sharing inandated under sections 365 and 1124(2), however, is often inore extensive than this remstatement justification would require. These more pervasive distributional effects can be at least partially explained by the common disaster conceptualization. The case of R.S. Pinellas Motel Partnership illustrates the risk-sharing features of these sections. ${ }^{65}$ The bankrupt debtor in Pinellas was a Ramada Inn franchisee. The franchise contract provided, inter alia, that the franchisor could terminate the contract with notice

which performance remains due to some extent on both sides."); see also Countryman, Executory Contracts in Bankruptcy (pt. 1), 57 Minn. L. Rev. 439, 450-62 (1973) (same).

64 Bankruptcy Code $\S 1124(2)$ provides that a class of claims is unimpaired if, notwithstanding a contractual right of acceleration, the reorganization plan cures any default, reinstates the contract rate of interest, and compensates the claimant for any damages resulting from the default. The distributional intent of this provision is suggested by the Senate Report on $\S 1124(2)$ :

The intervention of bankruptcy and the defaults represent a temporary crisis which the plan of reorganization is intended to clear away. The holder of a claim or interest who under the plan is restored to his original position, when others receive less or get nothing at all, is fortunate indeed and has no cause to complain.

S. Rep. No. 989, 95th Cong., 2d Sess. 120, reprinted in 1978 U.S. Code Cong. \& Admim. News 5787,5906 . There is an exception for certain contracts in $\S 365$ (c), although the prohibitions on assumption in $\S 365$ (c) are generally thought to be more appropriately conceived as prohibitions on assignınent in $\S 365(\mathrm{f})$. See National Bankruptcy Conference Report (Working Draft, March 1988).

65 R.S. Pinellas Motel Partnership v. Ramada Inns, Inc. (In re R.S. Pinellas Motel Partnership), 2 Bankr. 113 (Bankr. M.D. Fla. 1979). 
if the franchisee failed to maintain quality standards. Because Pimellas provided substandard facilities, Ramada elected to terminate the franchise, but the termination notice was not received until after Pinellas had filed for reorgamization under Chapter 11.

The court held that the attempt to terminate the franchise after the filing was an attempt to recover the property of the estate within section 362(a)(3) and was barred by the automatic stay. Despite the substandard facihities, the debtor in possession was able to assume the franchise under section 365(b)(1) by giving adequate assurances that the substandard facilities would promptly be brought into compliance with Ramada's standards. Clearly, absent bankruptcy, Ramada could have terminated Pinellas's franchise for substandard performance. The termination in this case thus cannot be explained as the reinstatement of a strategically breached contract. Pinellas directly raises the question: Why shouldn't the franchisee in bankruptcy have to play by the same rules as other franchisees?

The most satisfying explanation of Pinellas rests on the relational character of the franchise contract. The relationship between Pinellas and Ramada is a co-venture in which the parties share joint interests. Because Ramada will share some of the upside of the venture, it should share some of the downside as well. This conclusion is buttressed by the conditions of uncertamty and complexity that characterize the relational paradigm. Under these conditions, the expanded bargain model predicts that parties will often agree to share some risks. If certain contingencies are common, and both parties are risk averse, a risk-sharing scheme reduces uncertainty and thus reduces the cost of the risk for both. But in order to enforce such a risksharing rule, a companion requirenent would prohibit termination for any reason once the risk of bankruptcy materializes. While Ramada should be entitled to enploy alternative ineans of compelling coinphance with quality standards, the right of termination is trumped by bankruptcy. ${ }^{66}$

Viewed from this perspective, the assumption provisions of section 365 and section 1124(2) are "off the rack" contract terms that offer a convenient sharing rule as a hedge against the risk of business failure. By precluding termination upon insolvency, Ramada is required to continue to contribute to the venture and share some of the costs of insolvency. If the market value of the franchise exceeds the royalties paid by Pinellas in bankruptcy (a plausible assumption), then Pimellas is capturing economic rents that outside of

66 The United States Court of Appeals for the Ninth Circuit adopted this argument implicitly in Computer Coinmunications, Inc. v. Codex Corp. (In re Computer Communications, Inc.), 824 F.2d 725 (9th Cir. 1987) (umlateral termination of joint marketing agreement due to debtor's declaration of bankruptcy violates the autoinatic stay, even though terminating party was entitled to terminate agreement under state law). 
bankruptcy would be owned by Ramada. ${ }^{67}$ The benefits of such a sharing rule derive from the expectational benefits to equity and other general creditors who are participants in the co-venture. The restraints on termination refiected in sections 365 and 1124 reduce the risk of liquidation and enhance the pool of assets available for general distribution.

To be sure, these effects are not cost-free. Presumably, Ramada will adjust to the rule, either by avoiding relational financing arrangements or by mcreasing the price of the franchise. Moreover, implying a sharing rule only in bankruptcy invites Pinellas's management to invoke bankruptcy even when it is not in Pinellas's and Ramada's joint interest to do so. It remains, therefore, an empirical question whether the distributional effects that resnlt from this broader interpretation of section 365 and 1124 offer net benefits to the claimants as a group.

\section{B. Reimbursement For Delay Costs: The Time-Value Problem}

\section{The Valuation Dilemma}

A pervasive, if subtle, form of redistribution in bankruptcy is triggered whenever security interests in specific assets are converted into deferred cash payments. The filing of a bankruptcy petition operates as an automatic stay of any action by the secured creditor to collect claims or seize the collateral. ${ }^{68}$ A secured creditor can be reheved from a stay only by proving that the debtor has no equity interest in the secured assets and that the assets are not necessary for reorganization or that the collateral is jeopardized. ${ }^{69}$ In the meantime, the debtor in possession (or the bankruptcy trustee) may continue to operate the business so long as the secured party is given adequate protection. ${ }^{70}$

Assessing the question of whether the secured party is entitled to rehef from the stay and whether protection is adequate, raises vexing valuation questions. This is especially true when the protection offered is periodic cash payinents. Furthermore, a reorganization plan can be "crammed down"

67 This story may also help explain $\S 365(\mathrm{f})$, which permits a debtor to assign an executory contract, and hence capture those rents, even when the debtor has no other use for the asset. See 11 U.S.C. \& 365(f) (1982). The assignment case is more problematic, however, because it introduces a new party involuntarily into the relationship. We note for now only that the assignment rule of $\S 365$ (f) is not replicated in $\S 1124$.

6811 U.S.C. $\$ 362(a)(4)$ (1982) (the filing of a bankruptcy petition operates as a stay of "any act to ... perfect, or enforce any lien against property of the estate").

69 Id. § 362(d); see also Southwest Fla. Prod. Credit Ass'n v. Jacobsen J-J Ranch, Inc. (In re Jacobsen J-J Ranch, Inc.), 4 Bankr. Ct. Dec. (CRR) 245 (Bankr. M.D. Fla. 1978).

7011 U.S.C. $\$ 361$ (1982 \& Supp. IV 1986). The court has broad latitude in determining what protection is adequate, including provisions for replacement liens, periodic cash payments, or the "indubitable equivalent" of the creditor's asset claim. Id. 
over the objections of a class of impaired creditors if it offers cash payments that are "fair and equitable."71 Obviously, the sufficiency of the creditors' protection in each instance depends on how the creditors' interests are valued. $^{72}$

An important aspect of this question is whether an undersecured creditor is entitled to any protection for the costs of delay itself. The United States Supreme Court recently held in United States Savings Association of Texas $v$. Timbers of Inwood Forest Associates ${ }^{73}$ that the provisions of the Bankruptcy Code negated any inference that an undersecured creditor was entitled to compensation for the opportunity costs of delay caused by the bankruptcy process. Thus, as to the period during bankruptcy when the automatic stay is effective, delay costs can no longer be recovered.

The result in Timbers is rather plainly inconsistent with the simple creditors' bargain model, which views the automatic stay as a withdrawal of a secured creditor's state law rights of foreclosure. While bankruptcy pohicy might sensibly require the secured creditor to leave the asset in place for the greater good of the claimants as a group, nothing in that pohicy requires the secured creditor to bear any of the costs of the bankruptcy proceeding. Thus, Timbers is at odds with the simple creditors' bargain premise that the relative value of entitlements in bankruptcy should not deviate from those outside of bankruptcy, except insofar as necessary to implement the collective proceeding.

This deviation from the simple creditors' bargain is less clear, but evident nonetheless, at the conclusion of the bankruptcy case. At that time, a secured creditor will typically be offered deferred cash payments equivalent to the discounted present value of the collateral. Although time value is explicitly incorporated into the statute, ${ }^{74}$ the key to the conversion process is the choice of an appropriate discount rate. In order to avoid any distributional effects, the court must award a discount rate similar to the rate creditors would receive under state law for comparable collateral in the hands of a comparable (postbankruptcy) debtor. Assuming the presence of an acceleration clause, ${ }^{75}$ secured creditors are entitled to the entire outstanding prin-

7111 U.S.C. $\S 1129(b)(1)$ (1982).

72 See generally Fortgang \& Mayer, Valuation in Bankruptcy, 32 UCLA L. Rev. 1061 (1985) (valuation of assets, liabilities, and distributions).

73108 S. Ct. 626 (1988).

7411 U.S.C. $\S 1129$ (b)(2)(A)(i) (1982 \& Supp. IV 1986) (providing that a secured creditor receive over time the present value of its allowed secured claim in order for a proposed plan of reorganization to gain court approval).

75 Bankruptcy law provides such an acceleration clause as an "off the rack" rule under $\S 502$, subject to reinstatement under $\S 1124(2)$. See id. $\S \S 502,1124(2)$. 
cipal upon default. This amount, paid in cash, or in kind by seizure of the collateral, can then be reinvested at the current inarket rate of interest.

Some bankruptcy courts have awarded secured creditors discount rates similar to the current inarket rate. ${ }^{76}$ An even larger number of bankruptcy courts have dechined to follow this approach, but instead have adopted a variety of rates that vary froin the current inarket rate for similar loans. Frequently, it is clear that the courts endorse redistribution from secured creditors to unsecured creditors and equity interests. One commonly adopted rate is the rate payable by delinquent taxpayers, the average predomimant prime rate quoted by commercial banks to large businesses. ${ }^{77}$ Other courts have awarded the coupon yield rate of fifty-two week treasury bills. ${ }^{78}$ One court described this rate as "reasonably responsive to current economic conditions ... yet ... not an unfair burden on ... debtors."79 On the other hand, these courts beheve that the contract or market rate is "uureasonable and inequitable ... and would jeopardize an otherwise good plan to the detriment of other affected creditors and particularly the holders of unsecured claims."

Taken together, these cases reflect a strong vision of the bankruptcy process: secured creditors are not entitled to current inarket rates because protecting their interests in full will necessarily reduce the share awarded to unsecured creditors and equity interests. The failure to protect the "delay costs" secured creditors incur in bankruptcy thus seems to be a clear violation of the inaximization norm, untrue to the simple creditors' bargam.

\section{Non-reimbursement as Risk-Sharing Insurance}

A risk-sharing explanation of the time-value problem rehes on the difficulty of distinguishing ex ante between risks subject to individual control and those common risks that are so interrelated that no such risk reduction is feasible. We may simply be unable to decide who among shareholders and unsecured creditors deserve relief and who failed to exercise necessary prebankruptcy precautions. If this is the case, denying secured creditors protection against delay or selecting a less than compensatory discount rate are inethods of spreading the risk of common disaster insolvencies across the population of parties who use the bankruptcy process. They are, in effect,

76 See, e.g., Memphis Bank \& Trust Co. v. Whitman, 692 F.2d 427, 429, 431 (6th Cir. 1982); In re Scovill, 18 Bankr. 633, 634 (Bankr. D. Neb. 1982); In re Landmark at Plaza Park Ltd., 7 Bankr. 653, 657-58 (Bankr. D.N.J. 1980).

77 See, e.g., In re Caudle, 13 Bankr. 29, $37-38$ (Bankr. W.D. Tenn. 1981); In rè Ziegler, 6 Bankr. 3 (Bankr. S.D. Ohio 1980).

78 See, e.g., In re Fisher, 29 Bankr. 542, 543 (Bankr. D. Kan. 1983).

79 Ziegler, 6 Bankr. at 6.

80 Caudle, 13 Bankr. at 38. 
forms of insolvency insurance. ${ }^{81}$ Secured creditors in the ex ante bargain will simply assess a premium for assuming the burden of the risk-sharing component of the credit relationship. When bankruptcy occurs, the use of less than market discount rates provides a fairly simple way of structuring the payout for the insurance scheme. The insurance premium would be paid willingly by unsecured creditors if the exphicit premium cost were less than the increase in risk cost if all risks were borne individually.

In sum, the adoption of a systematic and predictable discount rate that returns less than full time value to the secured creditor is consistent, in theory, with the expanded creditors' bargain. If the incidence of common risks is significant, secured creditors, unsecured creditors, and equity claimants would predictably agree to insure against such risks through a risk-sharing scheine. Imposing delay costs on secured creditors so as to enhance the expected return for general creditors is a plausible means of administering such a scheme.

\section{Chapter 11 Reorganization}

\section{The Case For Reorganization}

Nowhere are the distributional effects of bankruptcy more pronounced, and their justification inore uncertain, than in corporate reorganization under Chapter 11. Indeed, as Douglas Baird has shown, the case for Chapter 11 reorganization is uneasy at best. ${ }^{82}$ The creditors' bargain perspective challenges the traditional justification for a reorganization proceeding. To be sure, total creditor wealth is often maximized by maintaining the going concern value of the firm. Going concern value, however, can be realized in a Chapter 7 hquidation by the simple expedient of a sale of the business to a third-party buyer. Furthermore, a third-party sale should generally be the optimal ineans of maximizing asset value. Such a sale generates market values that are easier to establish and fairer to administer; it promotes a search for firms that can be salvaged and enhances the expertise of buyers. By permitting each claimant's share to be accurately measured, a cash sale reduces conflicts among the various clainants. ${ }^{83}$

Even in cases where the distinct feature of the firm is the unique or idiosyncratic contribution of the owner-manager, a reorganization is not neces-

81 Query, however, why the form of the insurance would differ during the automatic stay in bankruptcy ( $\$ 361$ as interpreted by Timbers) from the rule after a bankruptcy plan has been confirmed $(\S 1129(\mathrm{~b})(2)(\mathrm{a})(\mathrm{i}))$.

82 Baird, The Uneasy Case for Corporate Reorganizations, 15 J. Legal Stud. 127 (1986).

83 See Roe, Bankruptcy and Debt: A New Model for Corporate Reorganization, 83 Colum. L. Rev. 527 (1983). An attempt to mimic such a result in the Chapter 11 context is set forth in Bebchuk, A New Approach to Corporate Reorganizations, 101 Harv. L. Rev. 775 (1988) (use of options to provide entitlements for different classes in the securities of a reorganized firm). 
sary to maximize asset values. Undervaluation problems-the traditional justification for the Chapter 11 process-could be solved in such cases by the owner-manager reacquiring the firm from the third-party buyer (or becoming a part of the buying syndicate).

A market-sale alternative, however, is appropriate only if no risk sharing is required (other than as already reflected in nonbankruptcy rules and contracts) or if risk-sharing features can be inserted into the distribution of the proceeds froin the sale. On the other hand, if certain forms of risk sharing are desirable, and if they justify adjustments in the relationships among various classes of claimants, the case for a distinct reorganization process is stronger. ${ }^{84}$

The case for reorganization is bolstered further if we make a more complex, "multirelational" assumption. Such an assumption increases the complexity of the risk-sharing arrangements and introduces the greater intractability of market solutions to valuation problems. Suppose that a general financing bank, several trade suppliers, a group of key employees, and the owner-manager have all made firm-specific investments in the enterprise. Assume furthermore that these contributions are synergistic. These synergies are a product of various economies of scale, coordination, and agglomeration. Under these conditions, it becomes very costly to bargain among all affected claimants in order to secure their participation in a buyout. Moreover, the parties must bargain over future contributions as well as past risksharing agreements. These bargaining difficulties are exacerbated by tine constraints. While a buyer ultimiately may be able to reach a bargaim with all of the affected parties, valuing such multirelational firms is costly, and search costs are high.

Can a reorganization process amehorate any of these problems? Some of the provisions of Chapter 11 are responsive to the difficulties of multiparty bargaining, while others arguably promote risk-sharing agreements. The problems of multiparty bargaining are ameliorated by rules permitting current inanagement to reinam as the debtor in possession and to make ordinary business decisions umimpeded by the ongoing efforts to reorganize. ${ }^{85}$

84 One could, of course, attempt to impose risk-sharing features on the distribution of the sale proceeds. But once the mechanical rules of $\S 726$ for distribution are abandoned, something like the rules found in Chapter 11 are necessarily reintroduced. See 11 U.S.C. $\S 726$ (1982 \& Supp. IV 1986). If that is so, not much would have been gained by resorting to Chapter 7 and then introducing risk-sharing rules into the distributional process.

85 See id. §§ 1107(a), 363(c)(1) (1982 \& Supp. IV 1986). Section 1107 permits the existing manageinent in a Chapter 11 case to reinain as debtor in possession with "all the rights ... powers . . . and duties" of the trustee. Among other rights, the trustee is authorized under $\S 363(\mathrm{c})(1)$ to "enter into transactions, mcluding the sale or lease of property of the estate, in the ordinary course of business ... and may use property of the estate in the ordinary course of business, without notice or a hearing." 
These provisions reduce the urgency in formulating a viable plan. Moreover, the disclosure requirements of section 1125 require each claimant to, in effect, "show its hand."86 Disclosure tends to reduce the strategic behavior that results from information asymmetries and impedes multiparty bargaining.

The impulse toward risk sharing, on the other hand, is encouraged by Chapter 11 rules providing leverage to unsecured creditors and residual claimants during the negotiation process. For example, section 1121(b) grants the debtor the exclusive right for 120 days to propose a reorganization plan. ${ }^{87}$ Studies on agenda influence confirm the substantial leverage this provides the debtor (and existing managennent) in negotiating over any proposal to restructure the firm. ${ }^{88}$

Notwithstanding these provisions, the ambitious objectives of Chapter 11 are threatened by substantial implementation problems. In order to give the firm a sound capital structure, the parties inust recapitalize to prevent the firm from being overburdened with debt and fixed interest charges. In turn, this presents a new problem. Not ouly inust the reorganization process determine gomg concern value, but now it inust determine the new capital structure as well. Thus, reorganization is necessarily a more complex and attenuated process and inevitably presents inany inore opportunities for abuse. .

\section{The Distributional Effects of Reorganization}

There are good reasons to believe that a Chapter 11 proceeding encourages substantial redistribution among groups of claimants, especially in cases of closely held, multirelational firms. A simple exainple may illustrate how the dynamics of reorganization promote redistribution. Assume Old Corp. enters Chapter 11 with the following debt structure: $\$ 3$ million is owed to secured bank and $\$ 4.5$ million is owed to trade creditors. Assume further that the going concern value of Old Corp. is $\$ 6$ million and that its liquidation value if assets are sold off piecemeal is $\$ 4.5$ million. Obviously, the bank's interest is to cash out its $\$ 3$ million secured claim immediately, since it has nothing to gain from waiting, and things could get worse. On the otlier hand, the owner-manager and other shareholders are motivated to wait under all conditions. Because the shareholders have little chance of currently realizing anything, they have nothing to lose from waiting (except

86 Id. § 1125 (1982 \& Supp. IV 1986) (any claimant soliciting acceptance of a reorganization plan must provide an approved disclosure statement eontaining adequate information such that a reasonable investor could make an informed judgment about the plan).

87 See 11 U.S.C. § 1121(b) (1982).

88 See Levine \& Piott, Agenda Influence and Its Implications, 63 Va. L. Rev. 561 (1977). 
for lost opportunities), and things could always get better. The third group, the trade creditors, have the best incentives to maximize the value of the firm because they have something to gain as well as something to lose by the choice between immediate liquidation and delay. Under these conditions, a simple maximization model argues for permitting the unsecured creditors to resolve the fate of the firm. Substantial case authority, however, suggests that this result is not likely to occur.

The case of In re Lionel Corp. ${ }^{89}$ evidences the reluctance of courts to embrace fully an asset-maximizing conception of reorganization. The debtor corporation in Lionel filed a Chapter 11 petition, and existing management reinained in control as debtor in possession. The firm had assets valued at $\$ 169$ million and habilities of $\$ 192$ million. The creditors' committee represented unsecured creditors whose claims totalled $\$ 136$ million. The key asset of the firm was the Dale Company, of which Lionel owned eighty-two per cent of the common stock. The debtor im possession decided to sell Dale for $\$ 43$ million under section 363(b), and the creditors committee (composed of unsecured creditors) approved the sale. ${ }^{90}$ The equity committee, however, opposed the sale, arguing that authorizing a section 363(b) sale would be to effectively bypass the Chapter 11 reorganization process.

The court thus confronted the question whether section 363(b) properly could be used to effect a sale of most of the corporate assets of a Chapter 11 firm. The court held that, $\mathrm{m}$ order to protect junior interests, there must be a stated business justification for the sale other than appeasing creditors. In this case, the only justification for the sale was pressure by the major unsecured creditors for a faster resolution of the proceeding, and the need for speed was not a qualifying reason.

In terms of asset maximization, the Lionel decision seems clearly wrong. If maximizing total creditor wealth is the objective, then the creditors' committee is the optimal decisionmaker. To disapprove a section 363(b) sale under these circumstances, therefore, can only encourage bankruptcy sharing by further restricting creditors' access to their share of the bankruptcy estate. These restraints serve to enhance the ability of certain unsecured

89 Committee of Equity Sec. Holders v. Lionel Corp. (In re Lionel Corp.), 722 F.2d 1063 (2d Cir. 1983); see also Official Comm. of Equity Sec. Holders v. Mabey, 832 F.2d 299 (4th Cir. 1987) (no authority to pay some creditors prior to consummation of plan of reorganization), cert. denied, $108 \mathrm{~S}$. Ct. 1228 (1988).

90 Bankruptcy Code $\S 363(\mathrm{~b})(1)$ provides that the trustee or debtor in possession nay, after notice and a hearing, sell or lease property of the estate outside of the ordinary course of business. Such "extraordinary" transactions are to be distinguished front those arising in the ordinary course of business, which are authorized under $\S 363(\mathrm{c})(1)$ without the requirement of notice and a hearing. See 11 U.S.C. $\$ 363$ (1982 \& Supp. IV 1986). 
creditors and equity interests to negotiate a reorganization plan that distributes soine creditor wealth to other claimants.

\section{Absolute Priority and Contribution}

It is tempting to suggest that cases like Lionel, and the procedural rules that offer further leverage to equity interests, are insignificant given the requirement of absolute priority retained by the "cram down" rules of section 1129(b). ${ }^{91}$ The absolute priority rule prohibits a class of interests from participating in a reorganization unless all superior classes have been compensated in full. Because debtor firms usually do not have sufficient assets to compensate outstanding claims fully, and because equity claims rank at the bottom, the absolute priority rule seems to exclude most equity holders from sharing in any reorganization.

The contribution rule, however, puts a well-estabhished gloss on absolute priority, thus softening the impact of section 1129(b) on equity holders. Under the contribution rule, equity interests are permitted to participate in a reorganization if they make a fresh contribution to the firm's capital, provided that the contributions are proportionate in value to equity's share of the reorganized company. ${ }^{92}$

At first glance, the contribution rule may appear to be consistent with absolute priority because it purports to require new value from equity. Yet giving equity the exclusive right to purchase a position in a reorganized firm is, by definition, a violation of absolute priority. The right to make a contribution is itself a valuable property right without regard to the conditions under which contribution is made. ${ }^{93}$ Furthermore, the contribution rule

91 Bankruptcy Code $\S 1129(b)$ authorizes the bankruptcy court to confirm a reorganization plan, notwithstanding the objections of an impaired class of claimants, if the plan does not discriminate unfairly and is "fair and equitable" to the dissenting classes. Id. §1129(b)(1). The "fair and equitable" language has been held to incorporate the judicially created absolute priority rule. Case v. Los Angeles Lumber Prods. Co., 308 U.S. 106, 115-19 (1939).

92 See Case, 308 U.S. 106 (establishing the rule requiring a proportionality between contribution and retained equity). For a thoughtful discussion of the redistributional effects of the contribution rule, see D. Skeel, The Uncertain State of an Unstated Rule: Bankruptcy's Contribution Rule Doctrine [in] In re Ahlers (unpublished manuscript on file with Virginia Law Review Association); see also Nimmer, Negotiated Bankruptcy Reorganization Plans: Absolute Priority and New Value Contributions, 36 Emory L.J. 1009, 1012 (1987) ("loss is distributed by bargaining").

93 Moreover, the contribution rule may violate the current wording of $\S 1129$ (b), although not the dicta of Case. As codified, the $\S 1129$ (b) version of the absolute priority rule prohibits retention by a junior class of anything "on account of" old interests if seniors have not been paid in full. See 11 U.S.C. $\$ 1129$ (b)(2)(C)(ii) (1982). Limiting new contributions to holders of old equity interests defines the new contributors in terms of their old interests. See also $D$. Skeel, supra note 92 , at $19-20$ (contribution rule conflicts with absolute priority by allowing equity holders to receive value on account of their former status). 
violates the maximization norm whenever the "value" of the equity participation exceeds the "value" of the contribution, which presumably is often the case. Otherwise, equity obviously would not propose the exchange.

The distributional effects of contribution might be trivial if the rule as interpreted by courts were strictly limited to contributions in "money or in money's worth." 94 But recently the stakes have been higher. In In re Ahlers, for example, the United States Court of Appeals for the Eighth Circuit confirmed a reorganization plan in which the equity interests promised to contribute future labor on the family farm. ${ }^{95}$ Although reversed by the Supreme Court, ${ }^{96}$ the Eighth Circuit's opinion in Ahlers offers further evidence of courts' willingness to accept substitutes for cash contributions so long as the contribution can be ineasured monetarily. ${ }^{97}$ Despite the reversal of Ahlers, ${ }^{98}$ the general acceptance of cash substitutes, even if they are seen as contributions to capital, enables equity to propose confirmable reorganization plans in contexts where reorganization would not otherwise occur..$^{99}$

94 See Case, 308 U.S. at 122 (equity holders' "participation must be based on a contribution in money or in money's worth, reasonably equivalent in view of all the circumstances to the participation of the [equity holder].").

95 Ahlers v. Northwest Bank Worthington (In re Ahlers), 794 F.2d 388 (8th Cir. 1986), rev'd, 108 S. Ct. 963 (1988).

96 Northwest Bank Worthington v. Ahlers, 108 S. Ct. 963 (1988).

97 Because the Ahlers' contribution could be measured in monetary terms, the majority suggested that the Case money-or-money's-worth standard was satisfied:

Certainly, a farmer's efforts in operating and inanaging his farm is [sic] essential to any successful farm reorganization, and this yearly contribution is measurable in money or money's worth. ... Accordingly, the farmer should be entitled to participate in the plan to the extent of this contribution, even though more senior claims are not provided for in full under the plan.

Ahlers, 794 F.2d at 402 . The Supreme Court disagreed, believing the case was squarely controlled by the "slippery slope" dicta in Case. Ahlers, 108 S. Ct. at 966-68 (citing Case, 308 U.S. at 122-23).

98 The reversal of Ahlers came as little surprise as other courts have been reluctant to recognize promises of future services as sufficient value to justify contribution. See, e.g., In re Stegall, 64 Bankr. 296, 299 (Bankr. C.D. Ill. 1986), aff"d, 85 Bankr. 510 (1987). (“Ahlers is the first and only case ever to hold that the promise of future labor is an adequate substitute for a new capital contribution.").

99 See, e.g., In re Potter Material Servs., Inc., 781 F.2d 99 (7th Cir. 1986) (cash and personal guarantee); Brown v. Brown's Indus. Umiforms, Inc. (In re Brown's Indus. Uniforms), 58 Bankr. 139 (Bankr. N.D. Ill., 1985) (pledge of personal finances); In re Landau Boat Co., 13 Bankr. 788 (Bankr. W.D. Mo. 1981) (combination of cash and loan commitments); Buffalo Savs. Bank v. Marston Enters. (In re Marston Enters.), 13 Bankr. 514 (Bankr. E.D.N.Y. 1981) (cash). See generally Baird \& Jackson, Bargaining After the Fall and the Contours of the Absolute Priority Rule, 55 U. Chi. L. Rev. 738, 741 (1988) ("[T]o the extent that the junior owners can offer new supplies, expertise, or capital on terms more favorable than anyone else, it is in everyone's interest that they do so."). 


\section{Common Disaster Explanations for Reorganization}

The persistent bias towards bankruptcy sharing revealed in Lionel, in the Eighth Circuit's opinion in Ahlers, and in the structural rules of Chapter 11 can, at least in theory, be justified by the expanded creditors' bargain. One justification for Chapter 11 distribution is diversification by risk sharing. For common risks, risk-averse parties would prefer to diversify. As we have seen, one inethod of accomplishing this is to spht and share. Sharing reduces both uncertainty and self-interested behavior. It is a desirable strategy whenever individual risk bearing would be unproductive. As before, given the costs of deciding whether insolvency resulted from a risk that had been individually allocated or from a risk that was to be shared equally, soine partial blurring of entitleinents may be a crude but effective response to the general problein.

A second explanation for the peculiar structure of Chapter 11 and its judicial gloss rests on the assumption of firm-specific investinent. The expanded creditors' bargain assuines that the owner-manager of a closely held firm frequently has sentimental or idiosyncratic value invested in the enterprise. Chapter 11 thus functions as a kind of rehabilitation insurance, a bargainedfor safeguard against the loss of idiosyncratic value. This conception appears to explain why bankruptcy courts recognize equity's exclusive right to invoke the contribution rule. ${ }^{100}$ Contribution is a peculiarly appropriate inethod for "relational" firms to insure against the nonpecuniary losses associated with dissolution.

A survey of contribution cases reveals patterns that are roughly congruent with this expanded conception of the hypothetical bargain: The contribution rule is generally invoked in proceedings to reorganize small, closely held firms. Businesses whose contribution-based reorganization proposals have been confirmed range froin a small building supply company to a uniform shop. ${ }^{101}$

In re Landau Boat Co. ${ }^{102}$ is illustrative of how courts have applied the contribution rule. The debtor's original reorganization plan was rejected because the proposal would have permitted equity to retain its interest without fully coinpensating unsecured creditors. The new plan then based the retention of equity on contribution by "subscribers" who would receive one share of stock in the reorganized firm for each dollar of contribution. The subscribers were also required to loan the firm $\$ 3$ per share of stock. The

100 Actually, contribution should probably be the manager's exclusive right. In a closely held firm, however, the overlap may be substantial enough.

101 See, e.g., Potter Material Servs., 781 F.2d. at 99; Brown's Indus. Uniforms, 58 Bankr. at 139; D. Skeel, supra note 92, at 7 n.23.

10213 Bankr. 788. 
bankruptcy court confirmed the plan over the objections of secured and unsecured creditors. ${ }^{103}$

The plan in Landau Boat clearly had a distributional effect, as evidenced by the creditors' objections. Nevertheless, the court approved the plan. Contribution was the only feasible ineans of reorganizing the cash-starved enterprise. The lesson is plain: when the debtor lacks needed cash, and equity is willing to provide it, courts will tend to approve the plan in order to facilitate reorganization, despite any distributional effects. ${ }^{104}$

\section{The Implementation Costs of Bankruptcy Sharing}

The preceding discussion shows that the common disaster conceptualization provides a richer and more textured franework for the ex ante bargain. Because the expanded inodel seeins to rationalize inany of the distributional effects of bankruptcy, it has both positive and normative appeal. This richer version of the hypothetical bargani supports a key theoretical claim: ex post redistribution is not necessarily incoinpatible with the ex ante objective of maximizing the value of the firm. In the case of the trustee's collection powers, the redistribution may restrain eve of bankruptcy misbelavior by those creditors who exercise de facto control over the debtor firm. Similarly, the impulse to impose delay costs on secured creditors inay be a means of inplementing a prearranged sharing scheine between secured and unsecured creditors, a scheine that would reduce risk for those interactive contingencies not subject to individual control. Chapter 11 reorgamization imposes similar delay costs on secured creditors, but introduces an additional factor: a distribution to equity claimants that serves to promote reorganizations. This, in turn, inay be a form of antidissolution insurance for those debtors who have made difficult-to-value investments in the firm.

Each of these effects inposes costs on secured creditors, who, in turn, pass the costs on to future debtors. But the model provides soine basis for arguing that in each case the costs would be assuined willingly by the other participants in the creditors' bargain. Thus far, however, we have assuned that all of the benefits froin bankruptcy sharing can be impleinented automatically in the bankruptcy process. In order to evaluate these effects in a more realistic environment, we now relax the assumption of perfect implementation and examine the various practical impediments to any bankruptcy sharing arrangeinent.

103 Id. at 794. The fact that the new contributions were not limited to the old equity owners reduces the force of the creditors' objection to the plan.

104 D. Skeel, supra note 92 , at 30. 


\section{Beyond Forum Shopping}

The problem of forum shopping confronts any bankruptcy system that is designed to complement an existing system of state law priorities. Different schemes for distributimg entitlements will necessarily create perverse incentives that motivate parties to use the bankruptcy process strategically. ${ }^{105}$ Unsecured creditors and debtors will opt for bankruptcy, if they can, when their share of the bankruptcy estate exceeds the value of their entitlements under applicable nonbankruptcy law. Secured creditors, on the other hand, will prefer to stay outside of bankruptcy if they are deprived im bankruptcy of otherwise existing entitlements. Parties will maneuver strategically to obtain the most favorable outcome, thus generating unnecessary social costs. Maintaining uniformity between state law and federal bankruptcy law could alleviate these problems.

The point is an inportant one, but if it is used to prove too much, it proves nothing. Indeed, the problem of perverse incentives is built into the very conception of the creditors' bargain. The central feature of any ex ante bargain is maximizmg total creditor wealth through collectivization. Yet, by restraining mdividual actions that are entirely permissible under state law, collectivization necessarily generates perverse incentives and encourages forum shopping. ${ }^{106}$ The question, then, is whether the mevitable costs of collectivization are justified by their corresponding benefits. On these terms, the common disaster formulation is analytically indistimguishable from the simple creditors' bargain conception. Both suggest an ex ante agreement to accept the irreducible costs of forum shopping to the extent that they purchase correspondingly greater expected benefits.

\section{Problems of Strategic Manipulation}

The problem of strategic manipulation of the bankruptcy process is central to the normative choice between the two visions of bankruptcy. There are two arguments that suggest that the expected costs of implementing some or all of the agenda of the expanded bargain would be so great as to justify a collective decision to abandon some or all of the risk-sharing goals. First, incorporating any of the approved distributions-whether risk sharing for diversification, contribution, or rehabilitation insurance-may generate

105 Bankruptcy is thus different from the usual solution to collective action problems. In fields such as oil and gas, the collective solution is exclusive. Bankruptcy law is relatively unique in having a solution to a collective action problem that is "optional," in that it runs parallel to an existing set of noncollective, debt-collection rules.

106 These probleins are reflected in the difficulties in generating a set of rules for determining when bankruptcy is appropriate. The common sense notion is that bankruptcy usually occurs too late, rather than too early, because of strategic self-selection, usually by equity owners. 
uncertainties that are qualitatively more costly than those associated with collectivization itself. Second, some or all of the sharing rules may present acute screening problems that jeopardize any corresponding benefits.

\section{a. Uncertainty Costs}

Distributional principles of any kind are inherently more difficult to implement than are allocational principles. The failure of the bankruptcy process to specify clearly drawn distributional rules that embody the equality and rehabilitative norns of bankruptcy is at least in part attributable to an essentially technological problem. Because distributional principles require an ex post analysis, they are not readily susceptible to ex ante rulemaking. As a consequence, even those principles that emerge from the ex ante bargain will generate additional uncertainties as to how entitlements will be distributed in bankruptcy.

Uncertainty as to legal outcomes imposes several different kinds of costs. Uncertainty may contribute to wasteful or excessive precautionary behavior. For example, when a secured creditor is uncertain about the discount rate that will be established in a section 1129(b) action, it will cliarge in advance a premium reflecting tlie maximum possible delay costs that are anticipated. This excessive precautionary beliavior is inefficient in the sense that if the parties could better predict the legal rule, they would be able to reach mutually beneficial agreements to reduce the risk. ${ }^{107}$ Furthernnore, some claimants in the bankruptcy process may be risk averse. Regardless of whetler the parties self-insure or obtain third-party imsurance, uncertainty cost is a dead weiglit social loss for risk-averse parties.

The important question, then, is whetler the incorporation of distributional effects generates uncertainties of a magnitude different from those produced by collectivization alone. This is an empirical question, but it does suggest a distmction between the effects of across-the-board redistributions and other bankruptcy sharing rules. Across-the-board provisions, such as the denial of postpetition interest sanctioned by Timbers, are confined by their explicit terms, and in that sense have a fixed and clearly defined jurisdiction.

The same cannot be said, however, for the occasional distributional impulses that appear throughout the bankruptcy process. The ad hoc bleeding of secured creditors, especially in Chapter 11 reorganizations, has no confining principle. It is neither mandated by, nor controlled by, the Bankruptcy Code. For mstance, the adoption by some courts of discount rates at

107 See C. Goetz, Cases and Materials on Law and Economics, 292-303 (1984); Calfee \& Craswell, Some Effects of Uncertainty on Compliance with Legal Standards, 70 Va. L. Rev. 965 (1984). 
less than current inarket values seems directly inconsistent with the statutory injunction that secured creditors are entitled to receive deferred cash payments "totaling at least" the present value of their secured claims. ${ }^{108}$ In short, the occasional distributional effects that result from a judicial gloss on the Bankruptcy Code, or that derive from the inherent uncertainties in valuation of assets, impose a significantly greater uncertainty cost on the bankruptcy process.

\section{b. Screening Costs}

Another unique cost of bankruptcy sharing derives from the distinction between desirable and undesirable distributions. If only certain distributions would be desirable in an ex ante bargain, failing to screen for those effects would impose costs that are not likewise imposed in a simple collectivization process. The problein of screening errors can be illustrated by a more careful examination of the contribution rule and the Ahlers case. Imitially, Ahlers appears to fit the pattern of inany of the cases confirming contribution-based plans. In theory, the contribution of future services by an owner-inanager is justifiable as one ineans of effecting a rehabilitation insurance scheme. This is especially true for activities such as farming, where the assumption of idiosyncratic value is quite plausible, and cash contributions are not feasible. The case for contribution in Ahlers does not survive close scrutiny, however. In order to justify the use of the contribution rule to effect rehabilitation insurance, the rule must operate as an effective screen. Reorganizations where contribution is appropriate inust be distinguished from those in which the rule should not be invoked. ${ }^{109}$

But screening for the right distributions is not easily done. Attempts to screen for types of cases that belong in bankruptcy are necessarily crude. Moreover, even if an entity appropriately belongs in bankruptcy, the desirability of a particular sharing rule turns on the type of risk or on the status of the owner-manager. Again, screening among cases is likely to be difficult and perhaps biased. The contribution doctrine, for example, has never been codified. Thus, the language of the statute provides nothing to assist in the contribution analysis. Given the uncertainties generated by the contribution rule, courts must rely on their own inpressionistic judgments as to whether a proposed contribution is consistent with the Code's objectives.

Even if we ignore our suspicion (bolstered by cognitive processes such as "presence") that courts strain to facilitate the reorganization of "attractive" debtors, it must be conceded that courts have few guidelines for implementing the contribution rule that will safely distinguish "deserving" debtors

10811 U.S.C. $\S 1129$ (b)(2)(A)(i)(II) (1982).

109 D. Skeel, supra note 92, at 31-32. 
from those who are not. ${ }^{110}$ In Ahlers, for example, the only basis for bankruptcy intervention would be to preserve the Ahlers' idiosyncratic imvestment. But since there were only two principal parties, they should have negotiated a sharing rule independently of bankruptcy. To explain why they did not, one has to argne either that the parties anticipated significant multiple creditors (unlikely under the facts of Ahlers) or that they were satisfied with bankruptcy's sharing rule (unlikely because, before the Eighth Circuit opinion in Ahlers, it would have been extremely difficult to predict the rule). In short, the rule the Eighth Circuit embraced in Ahlers ran a significant risk of implementing neither the simple nor the expanded creditors' bargam model of bankruptcy. ${ }^{111}$

Our earlier discussion of risk-bearing strategies illustrates the undesirable effects of an meffective screen. Parties who would be willing to pay the added cost to share common risks presumably would prefer not to pay to share those risks that can be reduced by individual precautions. Screening failures force claimants to pay for more bankruptcy sharing than they would have agreed to in the original creditors' bargain. Secured creditors, having borue the burden of redistribution that results when courts inisapply a sharing rule, will pass this cost on to future debtors. Those debtors who must rely on private credit for their financing needs are often small, capital-poor firns. Frequently, they have no alternative but to pay the inflated cost of credit.

Screening errors also have important feedback effects on the uncertainty costs described above. If the extent of the redistribution from secured creditor to equity claimants cannot be accurately predicted, secured creditors will be motivated to avoid bankruptcy altogether and to seek alternatives such as private workouts and state insolvency proceedings. Furthernore, each claimant in bankruptcy will engage in costly efforts to minimize its mdividual contribution to the bankruptcy sharing. This strategic maneuvering is a forin of rent-seeking behavior that erodes the gains from collectivization.

To the extent that the inability to screen for the desired distributions is systematic, courts will tend invariably to misapply those bankruptcy rules that are designed, whether deliberately or through inadvertence, to advance the desired distributional goals. This concern for excessive screening errors

110 Id. at 31-33.

111 At least in result, the reversal of Ahlers by the Supreme Court, see Ahlers, 108 S. Ct. 963 , supports this view. The same criticism might be true of Timbers, $108 \mathrm{~S}$. Ct. 626 . See supra text accompanying note 69 . Timbers is also a two-party case with no applicable going concern surplus. In Timbers, however, it might plausibly be asserted that the parties had implicitly agreed to bankruptcy's risk-sharing rule, in the form of no compensation for time value. This distinction may explam why the Supreme Court affirmed the result in Timbers but reversed Ahlers. 
provides a further point of distinction between broad-based and ad hoc distributional effects. The uncertainty with respect to cases such as Ahlers is symptomatic of the underlying uncertainty generated by any ad hoc distributional principle. The enhanced costs of implementing bankruptcy sharing rules, even where those rules might in theory be part of the ex ante bargain, threaten the very wealth maximization goals that drive the bargain itself.

\section{CONCLUSION: NoRMative IMPLications}

The preceding analysis suggests that substantial difficulties will attend attempts to accommodate maximization and distributional goals in bankruptcy. Several key normative imphications follow from this analysis. First, these operational problems should not obscure the fact that a single-minded focus on preserving the value of prebankruptcy entitleinents is not necessarily the optimal means of mirroring a hypothetical ex ante bargain annong the creditors. The expanded bargain model offers instead an alternative benchmark for evaluating the goals of the current bankruptcy systein. Our model suggests that various distributional objectives shape the bankruptcy process and that these objectives are entirely congruent with the goal of maximizing expected group welfare. The inefficiencies that we observe in bankruptcy may simply be a classic exainple of the "before and after" problem: the result of defective implementation of theoretically desirable objectives.

The central challenge, therefore, is to devise bankruptcy rules that better reflect both maximization and distributional norms. At this level, the analysis offers specific prescriptive guidance as well. Rules that attempt to redistribute bankruptcy assets in particular cases are peculiarly susceptible to exploitation. Case-by-case analyses sinply do not screen effectively between desired and disfavored redistributions. Instead these ad hoc distributions motivate the wasteful rent seeking behavior we have described above.

A preferable strategy for achieving bankruptcy's distributional goals would be to visualize the various distributional effects as a kind of "bankruptcy tax." If the distributional tax is certain and fixed, the parties have the capacity to adjust to the distributional rules. Furthermore, the more the tax is made certain and horizontally equitable, the less individual parties will be motivated to escape their share of the distributional burden. This suggests that across-the-board redistributions, such as the Timbers denial of postpetition interest for secured creditors, are preferable to the individualized distributional pohicies reflected in the Eighth Circuit's decision in Ahlers.

The extreme difficulty of crafting effective individualized distribution rules may also resolve a final puzzle suggested by the creditors' bargain conceptualization. If the bankruptcy process is best understood as the implementation of a consensual bargain ainong all affected groups, what then explains the inandatory character of the distributional scheme? For exainple, sup- 
pose that the common disaster risk sharing is, in fact, the outcome preferred by most creditors. Assume, however, that an individual secured creditor announces in advance that it does not imtend to participate in bankruptcy sharing. The creditor instead offers a price discount for the credit it will issue. Under current bankruptcy law, such contracting out would not be permissible. One explanation for the mandatory nature of the current bankruptcy systein derives from the technological difficulty of crafting rules that accoinphish both collectivization and distributional objectives. These operational constraints offer some justification for limitations on the traditional freedom to contract out.

The benefits of standardized distributional rules suggest that the traditional contractual freedom to opt out of the creditors bargain might sensibly be restricted in bankruptcy. Bankruptcy law is neither a pure contractarian nor a strictly regulatory legal regime. Rather, bankruptcy law limits individual choice to a few inodel forms (shareholders, secured creditors, unsecured creditors), each having been tested by timie and experience and thus carrying a reputable "brand name."112 These various options, and their associated legal entitleinents, have evolved over time. The priorities have been tested, and rules fixing the distribution have been adopted into positive law. ${ }^{113}$

To be sure, limiting options to only a few model forms imposes costs on those parties for whom the available options are ill-fitting and to whoin a tailor-made alternative would be preferable. The justification for this limitation is that, in the bankruptcy setting, the extraordinary benefits of standardization of distributional rules seein to trump the benefits of contractual freedoin for idiosyncratic participants in the process. ${ }^{114}$

Where this all leads reinams, predictably, an empirical question. In theory, incorporating a common disaster perspective into the creditors' bargam approach offers a richer vision of the bankruptcy process because it rationalizes soine of the distributional impulses that are unambiguously present in bankruptcy. Unhappily, the model also reveals the significant strams that bankruptcy sharing imposes on the bankruptcy process. Thus, the analysis, while providing a inore precise focus for the arguments, ultimately leaves unresolved the ongoing normative debate concerning the proper role for bankruptcy in the resolution of creditor claims.

We have suggested that the distributional effects of bankruptcy are a

112 For an analysis of similar concerns in the corporate context, see Coffee, No Exit? Opting Out, The Contractual Theory of the Corporation, and the Special Case of Remedies, 53 Brooklyn L. Rev. 919 (1988).

113 This discussion of evolution of standardized contract terms draws on the discussion in Goetz \& Scott, The Limits of Expanded Choice: An Analysis of the Interactions Between Express and Implied Contract Terms, 73 Calif. L. Rev. 261 (1985).

114 Id. 
bankruptcy tax imposed on the participants in the collective proceeding. ${ }^{115}$ To the extent that the tax revenues are used to support the welfare of the claimants as a group, one can visualize the parties agreeing to so burden themselves in an ex ante bargain. The further problem that the parties inust resolve, however, is that the bankruptcy distribution tax is not a purely exogenous cost that the parties can simply adjust to ex ante. Rather, the inagnitude of any distributional tax is a function of the bankruptcy law. If the rules for bankruptcy sharing were perfectly definable and enforceable, the theoretical appeal of the common disaster heuristic could be fully realized. Bankruptcy sharing rules that apply ouly in particular cases are necessarily ainbiguous, however, because they require an ex post evaluation of particular circumstances in order to trigger a contingent ex ante agreement to share. Under those inherent constraints, claimants have an incentive to expend resources to minimize the mcidence of the bankruptcy tax on them as individuals, thus reducing the wealth of the claimants as a group. Furthermore, bankruptcy proceedings such as Chapter 11 , which are designed to accoinphish these more complex goals, invite dissipation of the common pool by specialists, lawyers, accountants, and economists, who are similarly motivated to secure individual advantage at group expense.

115 See Goldberg, Comment: Economic Aspects of Bankruptcy Law, $141 \mathrm{~J}$. Institutional \& Theoretical Econ. 99, 101-02 (1985). 